\title{
Scientific Opportunities to Reduce Risk in Nuclear Process Science
}
P. Bredt ${ }^{(a)}$
M. Mcllwain ${ }^{(\mathrm{d})}$
A. R. Felmy ${ }^{(a)}$
B. A. Moyer ${ }^{(b)}$
P. A. Gauglitz ${ }^{(a)}$
A. P. Poloski ${ }^{(a)}$
D. Hobbs ${ }^{(\mathrm{c})}$
K. Subramanian ${ }^{(\mathrm{c})}$
S. $\mathrm{Krahn}^{(\mathrm{e})}$
J. D. Vienna $a^{(a)}$
N. Machara ${ }^{(e)}$
B. Wilmarth ${ }^{(\mathrm{c})}$

(a) Pacific Northwest National Laboratory

(b) Oak Ridge National Laboratory

(c) Savannah River National Laboratory

(d) Idaho National Laboratory

(e) U.S. Department of Energy (DOE-EM-21)

July 2008

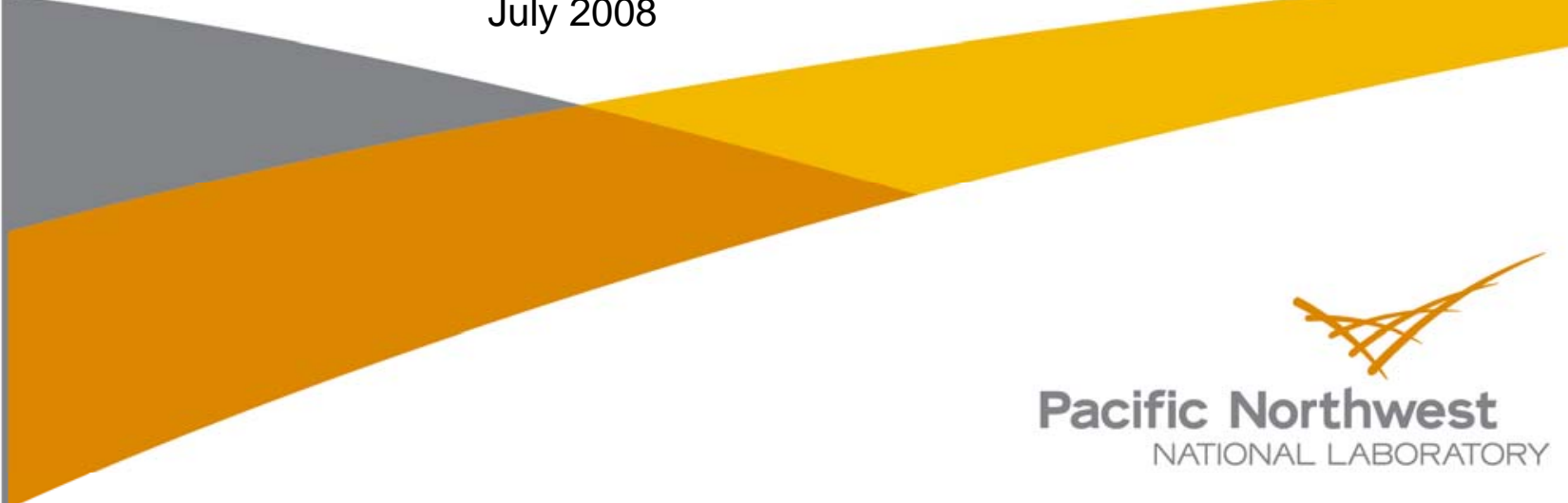




\title{
DISCLAIMER
}

This report was prepared as an account of work sponsored by an agency of the United States Government. Neither the United States Government nor any agency thereof, nor Battelle Memorial Institute, nor any of their employees, makes any warranty, express or implied, or assumes any legal liability or responsibility for the accuracy, completeness, or usefulness of any information, apparatus, product, or process disclosed, or represents that its use would not infringe privately owned rights. Reference herein to any specific commercial product, process, or service by trade name, trademark, manufacturer, or otherwise does not necessarily constitute or imply its endorsement, recommendation, or favoring by the United States Government or any agency thereof, or Battelle Memorial Institute. The views and opinions of authors expressed herein do not necessarily state or reflect those of the United States Government or any agency thereof.

\author{
PACIFIC NORTHWEST NATIONAL LABORATORY \\ operated by \\ BATTELLE \\ for the \\ UNITED STATES DEPARTMENT OF ENERGY \\ under Contract DE-ACO5-76RL01830
}

Printed in the United States of America
Available to DOE and DOE contractors from the
Office of Scientific and Technical Information,
P.O. Box 62, Oak Ridge, TN 37831-0062;
ph: (865) 576-8401
fax: (865) 5765728
email: reports@adonis.osti.gov

\footnotetext{
Available to the public from the National Technical Information Service, U.S. Department of Commerce, 5285 Port Royal Rd., Springfield, VA 22161 ph: (800) 553-6847 fax: (703) 605-6900

email: orders@nits.fedworld.gov online ordering: http://www.ntis.gov/ordering.htm
} 


\section{Scientific Opportunities to Reduce Risk in Nuclear Process Science}

P. Bredt ${ }^{(\mathrm{a})}$
A. R. Felmy ${ }^{(a)}$
P. A. Gauglitz ${ }^{(\mathrm{a})}$
D. Hobbs ${ }^{(\mathrm{c})}$
S. Krahn ${ }^{(\mathrm{e})}$
N. Machara ${ }^{(e)}$

M. McIlwain ${ }^{(d)}$

B. A. Moyer ${ }^{(b)}$

A. P. Poloski ${ }^{(a)}$

K. Subramanian ${ }^{(\mathrm{c})}$

J. D. Vienna ${ }^{(a)}$

B. Wilmarth ${ }^{(\mathrm{c})}$
(a) Pacific Northwest National Laboratory
(b) Oak Ridge National Laboratory
(c) Savannah River National Laboratory
(d) Idaho National Laboratory
(e) U.S. Department of Energy (DOE-EM-21)

July 2008

Prepared for the U.S. Department of Energy under Contract DE-AC05-76RL01830

Pacific Northwest National Laboratory

Richland, Washington 99352 


\section{Summary}

Cleaning up the nation's nuclear weapons complex remains as one of the most technologically challenging and financially costly problems facing the U.S. Department of Energy (DOE). Safety, cost, and technological challenges have often delayed progress in retrieval, processing, and final disposition of high-level waste, spent nuclear fuel, and challenging materials. Some of the issues result from the difficulty and complexity of the technological issues; others have programmatic bases, such as strategies that may provide undue focus on near-term goals or difficulty in developing and maintaining stakeholder confidence in the proposed solutions. We propose that independent basic fundamental science research, addressing the full cleanup life-cycle, offers an opportunity to help address these challenges by providing 1) scientific insight into the fundamental mechanisms involved in currently selected processing and disposal options, 2) a rational path to the development of alternative technologies should the primary options fail, 3) confidence that models that predict long-term performance of different disposal options are based upon the best available science, and 4) fundamental science discovery that enables transformational solutions to revolutionize the current baseline processes.

Over the last 3 years, DOE's Office of Environmental Management (EM) has experienced a fundamental shift in philosophy. The mission focus of driving to closure has been replaced by one of enabling the long-term needs of DOE and the nation. Resolving new challenges, such as the disposition of DOE spent nuclear fuel, have been added to EM's responsibilities. In addition, the schedules for addressing several elements of the cleanup mission have been extended. As a result, EM's mission is no longer focused only on driving the current baselines to closure. Meeting the mission will require fundamental advances over at least a 30-year window if not longer as new challenges are added. The overall intent of this paper is to foster a dialogue on how basic scientific research can assist DOE in executing its cleanup and environmental management mission.

In this document, we propose that such scientific investments not be focused solely on what may be viewed as current DOE needs, but also be based upon longer-term investments in specific areas of science that underpin technologies presently in use. In the latter regard, we propose four science theme areas: 1) the structure and dynamics of materials and interfaces, 2) coupled chemical and physical processes, 3) complex solution phase phenomena, and 4) chemical recognition phenomena. The proposed scientific focus for each of these theme areas and the scientific opportunities are identified, along with links to major risks within the initiative areas identified in EM's Engineering and Technology Roadmap (DOE 2008b). The authors encourage feedback from our colleagues in the nuclear waste and related fields. 



\section{Acronyms}

$\begin{array}{ll}\text { CST } & \text { crystalline silicotitanate } \\ \text { DLVO } & \text { Derjaguin, Landau, Verwey, and Overbeek (theory) } \\ \text { DOE } & \text { U.S. Department of Energy } \\ \text { DQMOM } & \text { Direct Quadrature Method of Moments } \\ \text { EM } & \text { Environmental Management (DOE) } \\ \text { HLW } & \text { high-level waste } \\ \text { LAW } & \text { low-activity waste } \\ \text { MSE } & \text { mixed-solvent-electrolyte } \\ \text { NRC } & \text { National Research Council } \\ \text { OET } & \text { Office of Engineering and Technology } \\ \text { PBE } & \text { population balance equation } \\ \text { SNF } & \text { spent nuclear fuel } \\ \text { R\&D } & \text { research and development } \\ \text { TRU } & \text { transuranic } \\ \text { WIPP } & \text { Waste Isolation Pilot Plant }\end{array}$





\section{Contents}

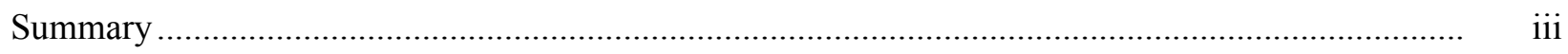

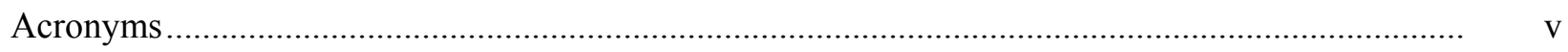

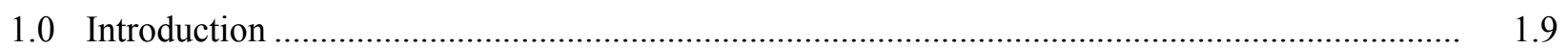

2.0 Structure and Dynamics of Materials and Interfaces....................................................... 2.1

2.1 Reactivity of Amorphous and Crystalline Materials .................................................... 2.1

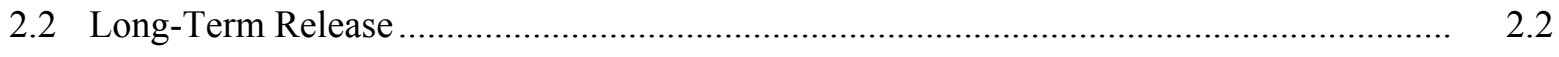

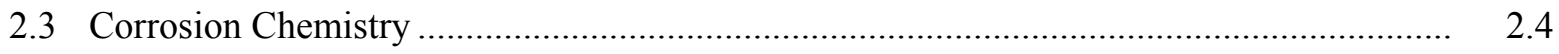

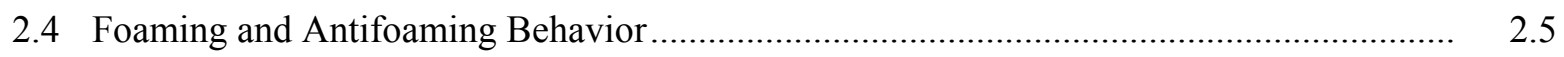

3.0 Coupled Chemical and Physical Processes in Environmental Applications ........................... 3.1

3.1 Rheological Properties of Colloidal Slurry Systems ........................................................ 3.1

3.2 Interaction of Colloidal Properties and Fluid Dynamics ............................................... 3.2

3.3 Environmental Process Applications................................................................................ 3.3

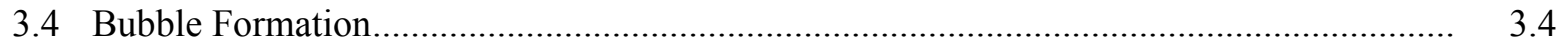

3.5 Gas Retention and Bubble Dynamics..................................................................... 3.4

3.6 Cold-Cap Reaction Mechanisms ………........................................................................ 3.5

4.0 Complex Solution Phase Phenomena in HLW Processing ...................................................

4.1 Role of Aqueous Solution Phase Phenomena .................................................................. 4.1

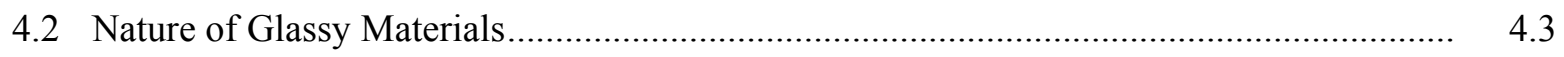

5.0 Chemical Recognition Phenomena in Environmental Applications........................................ 5.1

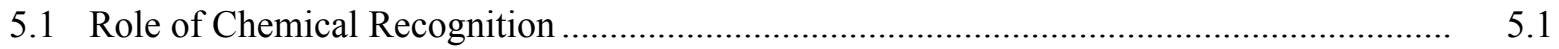

5.2 Design of New Reagents and Materials ….................................................................. 5.2

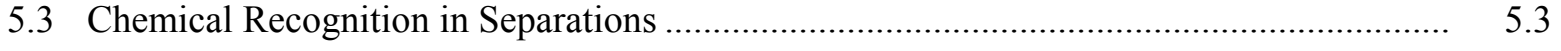

5.4 Sensing and Analytical Methods .............................................................................. 5.4

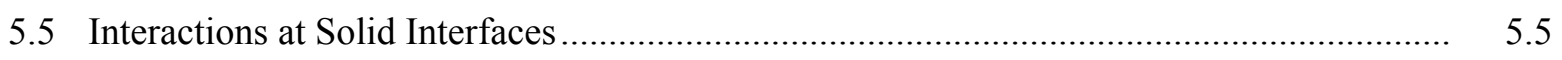

5.6 Recognition of Specific Contaminant Species ................................................................ 5.5

5.7 Conclusions on Application of Chemical Recognition ............................................... 5.6

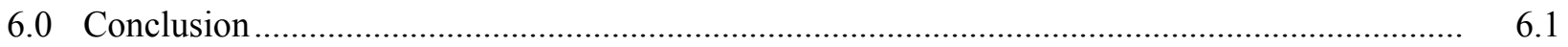

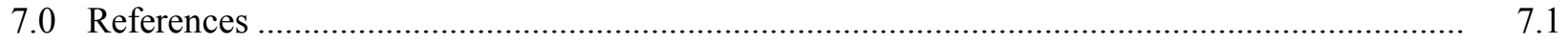




\section{Tables}

1.1. Scientific Opportunities to Reduce Risk in Nuclear Process Science .......................................... 1.10

1.2. Fundamental research is needed to develop applied solutions in the following areas to reduce technical risk and uncertainty in the DOE-EM Waste Processing mission. ................................ 1.12 


\subsection{Introduction}

The problem of retrieving, processing, and disposing of high-level waste (HLW), spent nuclear fuel (SNF), and other excess nuclear materials is nothing new. Numerous studies by the National Research Council (NRC) (NRC 1997, 2000, 2001, 2003, 2005, 2006, 2007) and U.S. Department of Energy (DOE) strategic planning efforts (DOE 1998a, 1998b, 2006, 2008a) have defined the importance of the issues and articulated the need for continuing investments in research and technology development focused on supporting DOE site needs. For example, a recent multi-year program plan developed by the DOE Office of Engineering and Technology (OET) identified 122 potential research activities to reduce the technical risk and uncertainty in the department's major HLW cleanup sites (DOE 2008c). These research activities were developed to address technology needs identified in the OET Roadmap (DOE 2008b) in the areas of Waste Storage, Waste Retrieval, Tank Closure, Pretreatment, and Stabilization. The large number of potential needs, coupled with the broad range of technological challenges spanning fundamental research to technology deployment, makes it difficult to define the precise role that basic science can play in the resolution of these issues; thus, the need for this paper.

There has been a fundamental shift in the DOE Office of Environmental Management's (EM's) mission focus and the opportunities for basic research over the last 3 years. EM was previously focused on addressing a fixed set of cleanup challenges using existing technologies. These activities were viewed as achievable with only incremental research and development (R\&D) investments centered on applied modifications to meet unique aspects of the cleanup. The mission focus is now based on reducing the long-term risks and uncertainties in cleanup challenges for DOE and the nation. New challenges have been added to EM's responsibilities, both broadening the mission and increasing the mission duration. As reflected in the OET Roadmap, two new areas have been added to the issues in Waste Processing: Spent Nuclear Fuel and Challenging Materials. Addressing these new elements will require the development of new processes incorporating innovative solutions to many fundamental science challenges. In addition, the schedules for addressing several elements of the previous mission have been extended. For example, the Waste Treatment Plant at Hanford was scheduled to begin operations in 2007 and finish immobilizing HLW within 20 years. Under the current baseline, the plant will begin operations in 2019 and finish in roughly 2049. This combination of an extended mission as well as additional challenges provides significant opportunities to reduce the risk and uncertainty through basic science research.

With these factors in mind, and based on the groundwork laid by previous reports (mentioned above), we have grouped the basic science needs into four theme areas: 1) the structure and dynamics of materials and interfaces, 2) complex solution phase phenomena, 3) coupled chemical and physical processes, and 4) chemical recognition phenomena. The scientific opportunities in each of these theme areas are described along with an articulation of how science can impact current and future DOE needs. Within each theme area, fundamental science questions are posed. These questions are summarized in Table 1.1.

As described above, the challenges facing the EM cleanup mission require investments spanning fundamental discovery-based research up to applied demonstrations and deployments of existing technology. In Table 1.2, we identify investments in fundamental research that will assist in reducing technical risk and uncertainty. These needs are divided into the seven strategic initiatives defined in EM's OET Roadmap (DOE 2008b). The first five of these-Waste Storage, Waste Retrieval, Tank Closure, Waste Pretreatment, and Stabilization - are under the Waste Processing Program Area. The final 
two initiatives - Spent Nuclear Fuel and Challenging Materials - were recently added to the Roadmap. These program areas and associated needs are still under development. Therefore, the risks in Table 1.2 for Spent Nuclear Fuel and Challenging Materials are preliminary, and associated science questions have not yet been developed. The overall intent of this paper is to foster a dialogue on how basic scientific research can assist the EM mission (DOE 2008a).

Table 1.1. Scientific Opportunities to Reduce Risk in Nuclear Process Science. Addressing these opportunities will require basic research ranging from fundamental chemical and physical investigations to advanced theoretical and computational modeling to technology development enabling transformational engineering solutions.

\begin{tabular}{|c|c|c|}
\hline Science Theme & Scientific Opportunities/Questions & EM Risks $^{(a)}$ \\
\hline \multirow{8}{*}{$\begin{array}{l}\text { Structure and } \\
\text { Dynamics of } \\
\text { Materials and } \\
\text { Interfaces }\end{array}$} & $\begin{array}{l}\text { Can we better characterize the heterogeneous materials in } \\
\text { waste tanks and improve our understanding of } \\
\text { dissolution/precipitation during retrieval and processing? }\end{array}$ & $\begin{array}{l}4,5,8,10,11,16,25,28 \\
29,30,31,35,48\end{array}$ \\
\hline & $\begin{array}{l}\text { Is it possible to more accurately characterize the chemical } \\
\text { changes that occur in slurries and solutions in real-time? }\end{array}$ & $\begin{array}{l}6,7,8,10,11,15,17,22 \\
23,26,27,33,34,39\end{array}$ \\
\hline & $\begin{array}{l}\text { Is it possible to develop alternative immobilization and } \\
\text { treatment technologies that mitigate the current issues } \\
\text { associated with long-term release? }\end{array}$ & $\begin{array}{l}10,11,18,19,20,21,22 \\
23,27,41,42,43,44\end{array}$ \\
\hline & $\begin{array}{l}\text { Can we extend our existing kinetic and thermodynamic } \\
\text { stability models of minerals and organic complexes over } \\
\text { hundreds or even thousands of years? }\end{array}$ & $18,19,20$ \\
\hline & $\begin{array}{l}\text { What is the nature of the solid-water interaction in } \\
\text { cementitious materials and associated microenvironments, } \\
\text { and how does one predict changes over geologic timescales? }\end{array}$ & $18,19,20,41,43,44$ \\
\hline & $\begin{array}{l}\text { How fast will glass react in the disposal environment? With } \\
\text { exceedingly long time scales, how will the various reactions } \\
\text { between glass and its surrounding environment progress? }\end{array}$ & 42,46 \\
\hline & $\begin{array}{l}\text { What are the mechanisms governing corrosion of materials } \\
\text { in contact with high-salt aqueous systems, and what are the } \\
\text { additional effects of radiation on these materials? }\end{array}$ & $1,2,3,9,13,24,33,34$ \\
\hline & $\begin{array}{l}\text { What are the mechanisms of complex surface chemistry } \\
\text { modifications and their impacts on foaming and antifoaming } \\
\text { for mixtures of insoluble particle species in concentrated } \\
\text { electrolyte solutions? }\end{array}$ & $5,6,13,17,40$ \\
\hline \multirow[t]{2}{*}{$\begin{array}{l}\text { Complex } \\
\text { Solution Phase } \\
\text { Phenomena }\end{array}$} & $\begin{array}{l}\text { Can we predict the thermodynamics of concentrated } \\
\text { electrolyte and mixed-solvent-electrolyte systems to very } \\
\text { high concentrations? }\end{array}$ & $\begin{array}{l}4,5,8,10,11,16,25,27 \\
28,29,30,31,35,37,38 \\
48\end{array}$ \\
\hline & $\begin{array}{l}\text { How do changes in ion solvation and chemical speciation in } \\
\text { concentrated electrolytes impact water activities and } \\
\text { exchange rates and hence the kinetics of precipitate } \\
\text { formation or dissolution? }\end{array}$ & $\begin{array}{l}4,5,8,10,11,16,25,27 \\
28,30,31,35,38,48\end{array}$ \\
\hline
\end{tabular}


Table 1.1 (Contd)

\begin{tabular}{|c|c|c|}
\hline Science Theme & Scientific Opportunities/Questions & EM Risks $^{(\mathbf{a})}$ \\
\hline & $\begin{array}{l}\text { How do we predict the evolution of vapor phase species from } \\
\text { tank supernatants resulting from radiolysis and changing } \\
\text { tank chemistry? }\end{array}$ & $3,7,13,24,43,45$ \\
\hline & $\begin{array}{l}\text { What is the nature of the glassy state? Molecules in a glass } \\
\text { are arranged much like those in liquids but are more tightly } \\
\text { packed. Where and why does liquid end and glass begin? }\end{array}$ & $25,42,44,46$ \\
\hline \multirow{8}{*}{$\begin{array}{l}\text { Coupled } \\
\text { Chemical And } \\
\text { Physical } \\
\text { Processes }\end{array}$} & $\begin{array}{l}\text { Can we expand our current fundamental models of colloidal } \\
\text { behavior to predict variability and dynamics in more } \\
\text { complex chemical and physical systems? }\end{array}$ & $\begin{array}{l}4,5,6,8,10,11,12,13,1 \\
4,28,31,32,33,34,40\end{array}$ \\
\hline & $\begin{array}{l}\text { Can advanced computational fluid dynamics techniques } \\
\text { predict rheological structure and the resulting rheological } \\
\text { behavior of complex fluids under varying flow conditions? }\end{array}$ & $\begin{array}{l}8,11,12,13,14,15,26,3 \\
1,32,33,47,45,46\end{array}$ \\
\hline & $\begin{array}{l}\text { Can the thixotropic rheological properties be predicted } \\
\text { through a combination of rheological structure modeling and } \\
\text { computational fluid dynamics under transient conditions? }\end{array}$ & $\begin{array}{l}11,12,13,14,15,32,33 \\
45,46,47\end{array}$ \\
\hline & $\begin{array}{l}\text { Can the yield stress of slurries be predicted through a } \\
\text { combination of dynamic rheological structure models and } \\
\text { colloidal properties? }\end{array}$ & $\begin{array}{l}4,5,6,8,10,11,12,13,1 \\
4,28,31,32,33,34,40\end{array}$ \\
\hline & $\begin{array}{l}\text { Can advanced computational fluid dynamics techniques } \\
\text { assist in predicting the performance of complex processing } \\
\text { equipment with thixotropic non-Newtonian fluids? }\end{array}$ & $\begin{array}{l}11,12,13,14,15,32,33 \\
45,46,47\end{array}$ \\
\hline & $\begin{array}{l}\text { What is the nature of bubble slurry interactions that } \\
\text { influence the distribution of bubble sizes in multiphase } \\
\text { slurries? }\end{array}$ & $6,13,32,40$ \\
\hline & $\begin{array}{l}\text { What is the nature of bubble retention and release on the } \\
\text { microscopic level, and what are the effects of slurry } \\
\text { composition? }\end{array}$ & $5,6,13,40$ \\
\hline & $\begin{array}{l}\text { Can cold-cap behavior and reactions be predicted with } \\
\text { broadly varying chemical compositions through a better } \\
\text { fundamental understanding of the interplay between } \\
\text { reactions of solid, liquid, and gas phases? }\end{array}$ & $33,41,43,45,46$ \\
\hline \multirow[t]{4}{*}{$\begin{array}{l}\text { Chemical } \\
\text { Recognition } \\
\text { Phenomena }\end{array}$} & $\begin{array}{l}\text { What are the fundamental interactions that maximize } \\
\text { differences in binding affinity and thereby maximize the } \\
\text { selectivity of binding phenomena? }\end{array}$ & $\begin{array}{l}7,9,18,20,21,22,23 \\
25,35,36,37,38,39\end{array}$ \\
\hline & $\begin{array}{l}\text { What is the nature of the interactions of the components of } \\
\text { matrix environments with target species of interest for } \\
\text { separations and sensing? }\end{array}$ & $\begin{array}{l}4,5,8,9,10,11,15,16,1 \\
7,18,19,21,23,28,29,3 \\
7,38,41,43\end{array}$ \\
\hline & $\begin{array}{l}\text { Can the structure of complexes and the thermodynamics of } \\
\text { complexation processes involving small donor molecules and } \\
\text { ions be predicted in condensed media? }\end{array}$ & $\begin{array}{l}\text { 7,9,18,20,21,22,23, } \\
25,35,36,37,38,39\end{array}$ \\
\hline & $\begin{array}{l}\text { Can molecules and materials be designed to have } \\
\text { predictable binding properties for target contaminant }\end{array}$ & $\begin{array}{l}7,9,18,20,21,22,23 \\
25,35,36,37,38,39\end{array}$ \\
\hline
\end{tabular}


Table 1.1 (Contd)

\begin{tabular}{|l|l|l|}
\hline Science Theme & \multicolumn{1}{|c|}{ Scientific Opportunities/Questions } & \multicolumn{1}{|c|}{ EM Risks $^{(\mathbf{a})}$} \\
\hline & $\begin{array}{l}\text { species? Can functional attributes be incorporated into the } \\
\text { molecular design so that the designed receptors behave } \\
\text { predictably in separations or sensing? }\end{array}$ & \\
& $\begin{array}{l}\text { How can receptors be designed to function efficiently in } \\
\text { different types of separation systems? }\end{array}$ & $\begin{array}{l}7,9,18,20,21,22,23, \\
25,35,36,37,38,39\end{array}$ \\
\cline { 2 - 3 } & $\begin{array}{l}\text { How can reporter groups, such as fluorophores and } \\
\text { chromophores, be coupled with binding groups and tethered } \\
\text { to surfaces to most efficiently signal binding without } \\
\text { interfering with the binding process itself? }\end{array}$ & $7,17,21,22,23,39$ \\
& $\begin{array}{l}\text { What is the structural nature of contaminant species on or in } \\
\text { complex solid materials, such as building materials, soils, } \\
\text { and metals, and what chemistry can be applicable to its } \\
\text { forced release? }\end{array}$ & $\begin{array}{l}8,9,10,11,16,18,19, \\
20,21,22,23\end{array}$ \\
& $\begin{array}{l}\text { What are the chemical speciation and bonding preferences of } \\
\text { a contaminant of interest in its matrix, including influences } \\
\text { of shape and H-Bonding? }\end{array}$ & $21,22,23,36,37,39$ \\
\hline
\end{tabular}

Table 1.2. Fundamental research is needed to develop applied solutions in the following areas to reduce technical risk and uncertainty in the DOE-EM Waste Processing mission. These range from fundamental chemical and physical data to advanced theoretical and computational models to technology development, enabling transformational engineering solutions. Categories here are derived from the OET Roadmap.

\begin{tabular}{|c|c|}
\hline Category & Risks and Uncertainties \\
\hline Waste Storage & $\begin{array}{l}\text { 1. Low temperature in-tank sealing technologies compatible with waste chemistry } \\
\text { and storage systems to enable tank repairs } \\
\text { 2. Mechanisms governing general corrosion, pitting, and stress corrosion cracking, } \\
\text { including effects of waste aging and temperature with time to support tank life } \\
\text { extension } \\
\text { 3. Reaction pathways in HLW slurries producing volatile components to mitigate } \\
\text { the risks of headspace corrosion, tank failure, ventilation system failure, and } \\
\text { occupational exposure } \\
\text { 4. Effects of storage conditions and aging on morphology and surface } \\
\text { characteristics of salt and sludge waste, including the role of water on surface } \\
\text { chemistry, as they affect continued storage, retrieval, and processing } \\
\text { 5. Effects of waste evaporation and blending operations on waste properties } \\
\text { impacting retrieval, transport, and flammable gas safety basis } \\
\text { 6. Chemical and physical processes governing gas retention and release, including } \\
\text { submerged bubble retention and gaseous floating layers impacting flammable gas } \\
\text { safety and general tank operations }\end{array}$ \\
\hline
\end{tabular}


Table 1.2 (Contd)

\begin{tabular}{|c|c|}
\hline Category & Risks and Uncertainties \\
\hline & $\begin{array}{l}\text { 7. Mercury compounds in waste systems and new monitoring technologies to } \\
\text { mitigate impacts on processing and reduce personnel exposure }\end{array}$ \\
\hline Waste Retrieval & $\begin{array}{l}\text { 8. Chemical and physical properties of dried wastes, including salt heels and } \\
\text { annular sludge needed to support retrieval and waste acceptance at treatment } \\
\text { plants } \\
\text { 9. Oxalic acid and other novel leaching agents interaction during heel removal to } \\
\text { mitigate carbon steel tank corrosion and flammable gas generation rates } \\
\text { 10. Existing mineral phases, condensation of new minerals, and co-deposition of } \\
\text { radionuclides on metal surfaces that increase source terms } \\
\text { 11. Chemical and physical properties of insoluble heels formed that will be generated } \\
\text { during complex retrieval and blending operations in staging tanks to enable their } \\
\text { eventual retrieval and disposal } \\
\text { 12. Physical properties of the tank waste to mitigate system failures, including line } \\
\text { plugging, pumping failures, and feed variability } \\
\text { 13. Physical and chemical processes leading to foam, crust, and floating layer } \\
\text { formation during retrieval to mitigate impacts on tank scaling and flammable gas } \\
\text { safety } \\
\text { 14. Rheological characterization of wastes as well as mixing and transport designs to } \\
\text { support homogeneous delivery of feeds to treatment plants } \\
\text { 15. Heel retrieval technologies and chemical models insufficient to ensure waste } \\
\text { acceptance at treatment plants } \\
\text { 16. Models for saltcake draining and dissolution to predict solution chemistry, rates, } \\
\text { dissolution methods, and radionuclide partitioning enabling the optimization of } \\
\text { retrieval-system designs and operation } \\
\text { 17. Chemical properties of tank waste needed to support acceptance and process } \\
\text { ability }\end{array}$ \\
\hline Tank Closure & $\begin{array}{l}\text { 18. Interactions of waste with the surrounding fill and near vadose zone to reduce the } \\
\text { migration of waste that has already leaked or may leak during retrieval } \\
\text { 19. Heel chemistry and associated radiochemical source terms following retrieval } \\
\text { activities, including modified sluicing to enable selection of appropriate tank fill } \\
\text { materials } \\
\text { 20. Improved stabilization forms as alternatives to baseline grout and consolidated } \\
\text { low-strength materials } \\
\text { 21. In-tank method to analyze residual materials, including components driving } \\
\text { performance assessment }\left({ }^{99} \mathrm{Tc},{ }^{79} \mathrm{Se},{ }^{129} \mathrm{I} \text {, and }{ }^{237} \mathrm{~Np} \text { ) and waste acceptance }\right. \\
\text { (particle size, percent solids, etc.) } \\
\text { 22. Sensors for radionuclides in soil and groundwater at tanks will enable long-term } \\
\text { monitoring. }\end{array}$ \\
\hline
\end{tabular}


Table 1.2 (Contd)

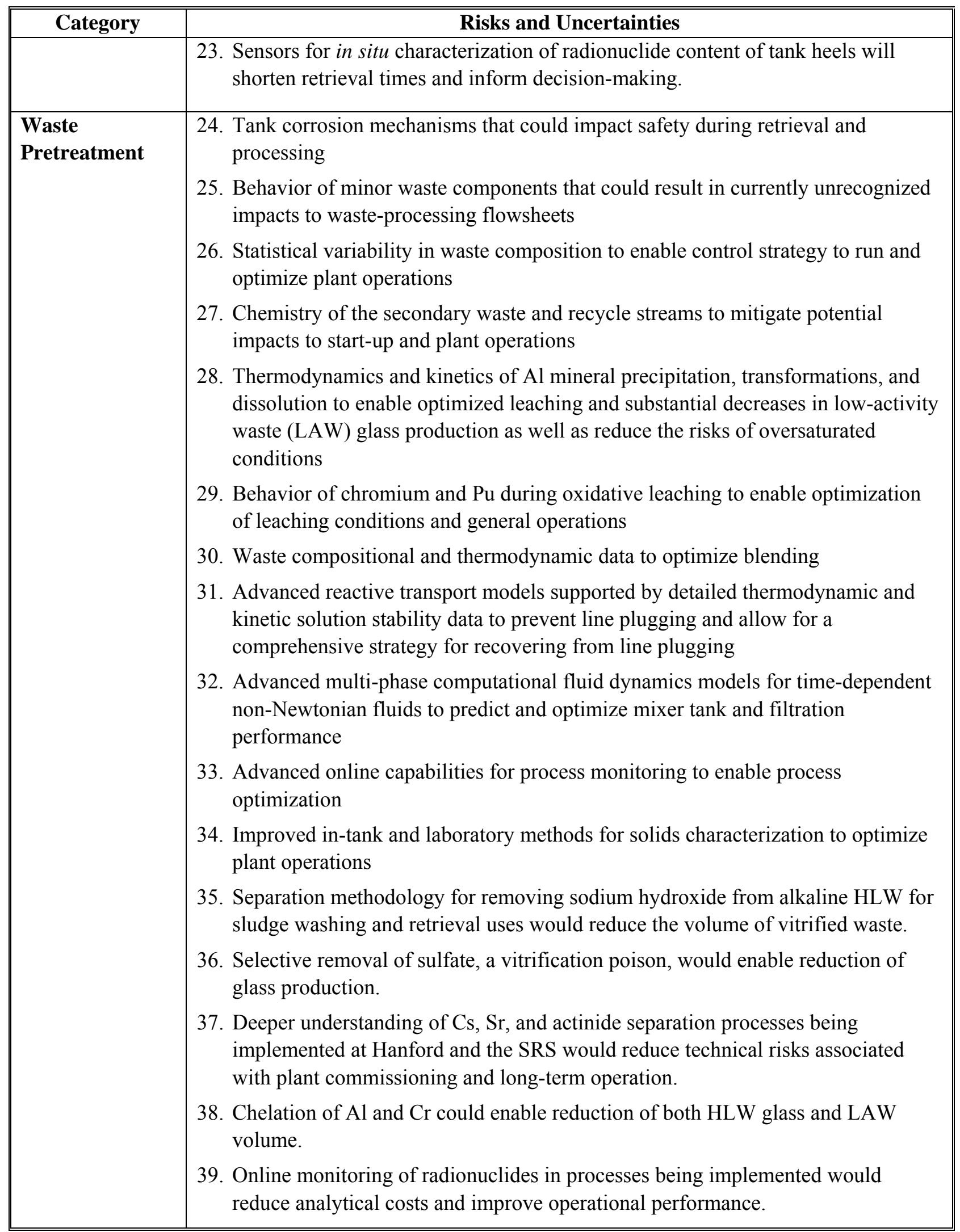


Table 1.2 (Contd)

\begin{tabular}{|c|c|}
\hline Category & Risks and Uncertainties \\
\hline & $\begin{array}{l}\text { 40. Foam formation and destruction in process streams to reduce impacts to } \\
\text { processing and improved flammable gas safety }\end{array}$ \\
\hline Stabilization & $\begin{array}{l}\text { 41. Vault science and technology enabling improvements in performance assessment } \\
\text { 42. Alternative HLW glasses with increased waste loading needed to boost } \\
\text { throughput and reduce canister count } \\
\text { 43. Grout curing and variations with formulations needed to ensure long-term } \\
\text { performance and reduce the release of volatile components } \\
\text { 44. Alternative LAW and secondary waste forms to mitigate the impacts of low } \\
\text { LAW melter throughput } \\
\text { 45. Cold cap chemistry, including flash reactions, off-gas, and overall melting } \\
\text { reactions and rates to optimize throughput, minimize refractory corrosion, and } \\
\text { reduce off-gas and recycle streams } \\
\text { 46. Liquidous-glass transition to model and predict the solubility of limiting } \\
\text { components, enabling optimized formulations, and to increase waste loading, } \\
\text { optimize melt rates, reduce melter temperature, and increase throughput } \\
\text { 47. Grout rheological and physical properties to support pumping operations and } \\
\text { filling of ancillary systems, including transfer lines and cooling coils } \\
\text { 48. New approaches to reducing the content of waste components, such as aluminate, } \\
\text { sodium, and sulfate, that determine glass volume to aid supplemental treatment }\end{array}$ \\
\hline $\begin{array}{l}\text { Spent Nuclear } \\
\text { Fuel }\end{array}$ & $\begin{array}{l}\text { 49. U metal oxidation mechanisms and rates needed to reduce technical risks } \\
\text { associated with selection and implementation of treatment options for U-metal- } \\
\text { containing materials } \\
\text { 50. Technical basis at Yucca Mountain for acceptance of metallic uranium and other } \\
\text { non- } \mathrm{UO}_{2} \text { fuels } \\
\text { 51. Thermodynamics and kinetics of water release from } \mathrm{Al}(\mathrm{OH})_{3} \text { required to address } \\
\text { transportation of Al-clad fuels } \\
\text { 52. Long-term chemical behavior of decay products from activation and fission } \\
\text { products as well as temperature histories to reduce uncertainties in fuel chemistry } \\
\text { and electronic structure that is challenging container integrity and the validity of } \\
\text { reactive transport models } \\
\text { 53. Mechanisms leading to degradation of DOE aluminum-clad spent fuels to ensure } \\
\text { safe storage } \\
\text { 54. Alternative sealing technologies enabling advanced canister closures in high- } \\
\text { radiation environments } \\
\text { 55. Advanced neutron absorbers performing over geological timescales to enable } \\
\text { safe storage in national repository }\end{array}$ \\
\hline
\end{tabular}


Table 1.2 (Contd)

\begin{tabular}{|c|c|}
\hline Category & Risks and Uncertainties \\
\hline & $\begin{array}{l}\text { 56. Fissile element redistribution during corrosion of DOE fuels to reduce } \\
\text { conservatism in current design and associated cost } \\
\text { 57. Alternative treatment flowsheet for Fast Flux Test Facility Na and K bonded } \\
\text { fuels to mitigate transport risks and waste acceptance risks to treatment at Idaho } \\
\text { and/or direct shipment to Yucca Mountain } \\
\text { 58. New technologies for nondestructive assay of plutonium and other isotopes in the } \\
\text { high-radiation environments of spent fuels for wet and dry storage to enable } \\
\text { flowsheet development, ensure safe storage, and improve accountability }\end{array}$ \\
\hline $\begin{array}{l}\text { Challenging } \\
\text { Materials }\end{array}$ & $\begin{array}{l}\text { 59. Chemical and electronic structure changes arising from radiolytic decay in Cs, Sr, } \\
\text { and other sealed capsules to assess long-term integrity and enable the } \\
\text { development of disposal options } \\
\text { 60. Corrosion hindering long-term performance of } 3013 \text { containers } \\
\text { 61. Tritium absorption and desorption thermodynamics and kinetics in structural } \\
\text { materials and components to support safety basis } \\
\text { 62. Transuranic (TRU) element adsorption and penetration of surfaces to enable } \\
\text { development of improved decontamination technologies needed to reduce the } \\
\text { volume of material sent to the Waste Isolation Pilot Plant (WIPP) } \\
\text { 63. Thermodynamic and chemical data on Pu-containing materials needed to support } \\
\text { processing and stabilization } \\
\text { 64. Chemical and radiolytic hydrogen gas generation mechanisms to enable TRU } \\
\text { transportation to WIPP } \\
\text { 65. Alternative waste forms and advanced melter technologies needed to stabilize } \\
\text { excess nuclear materials, including Pu } \\
\text { 66. Reaction mechanisms driving gas generation in } 3013 \text { canisters and other long- } \\
\text { term storage containers to safe storage } \\
\text { 67. Improved technologies to monitor the integrity and contents of } 3013 \text { canisters } \\
\text { and other long-term storage containers to safe storage and accountability } \\
\text { 68. Advanced non-intrusive characterization technologies, including the } \\
\text { measurement of chemical, physical, and radiological properties, to enable the } \\
\text { development of treatment options and accountability }\end{array}$ \\
\hline
\end{tabular}




\subsection{Structure and Dynamics of Materials and Interfaces}

Scientific challenges associated with HLW retrieval and treatment include an improved understanding of the structure and dynamics of the materials and interfaces. This includes the wastes themselves as well as waste storage and processing equipment and the final waste forms. The waste solids are a combination of minerals and amorphous compounds ranging from crystalline saltcake waste to insoluble sludge. Compounding the composition complexity of the tank wastes is the presence of organic solvents and organic complexants used in some of the chemical separation processes at the facilities along with the radiolytic and chemical degradation of these organic compounds. The behaviors of wastes, including particle agglomeration and coalescence, foaming, and solution/vapor interactions, must be predicted and controlled during storage and processing. Challenges related to tank closure and residual waste include 1) understanding the reactivity of amorphous and crystalline solids, 2) the quantification of the long-term contaminant release from the residual waste, 3) the impact of tank filling materials and the corrosion of steel tank liners on contaminant chemistry, and 4) the fate/transport of contaminants in the environment.

\subsection{Reactivity of Amorphous and Crystalline Materials}

The solids present in waste tanks at DOE facilities were formed under unique conditions of solution composition, temperature, and radiolysis that in many cases have varied over the 60 -year history for some of the tanks. The solids are a combination of minerals and amorphous compounds comprising relatively soluble saltcake waste and less soluble sludge. Saltcake was formed by neutralizing the nitric acid waste with $\mathrm{NaOH}$ to protect the steel liners of the tanks. Saltcake formation was enhanced by evaporation in the tanks. The primary mineral salts in saltcake are nitratine $\left(\mathrm{NaNO}_{3}\right)$ and $\mathrm{NaNO}_{2}$; however, other minerals and amorphous solids are likely trapped in the saltcake. The primary minerals encountered in sludge are common minerals such as gibbsite $\left[\mathrm{Al}(\mathrm{OH})_{3}\right]$, böhmite $[\mathrm{AlO}(\mathrm{OH})]$, hematite $\left[\mathrm{Fe}_{2} \mathrm{O}_{3}\right]$, and unspecified aluminosilicates (Deutsch et al. 2005a). In addition, uncommon minerals, such as čejkaite $\left[\mathrm{Na}_{4}\left(\mathrm{UO}_{2}\left(\mathrm{CO}_{3}\right)_{3}\right]\right.$, lindbergite $\left[\mathrm{MnC}_{2} \mathrm{O}_{4} \cdot 2 \mathrm{H}_{2} \mathrm{O}\right]$, cancrinite $\left[\mathrm{Na}_{6}\left(\mathrm{Al}_{6} \mathrm{Si}_{6} \mathrm{O}_{24}\right)\left(\mathrm{CaCO}_{3}\right)\left(\mathrm{H}_{2} \mathrm{O}\right)_{2}\right]$, and dawsonite $\left[\mathrm{NaAlCO}_{3}(\mathrm{OH})_{2}\right]$, have also been detected in one or more tanks (Krupka et al. 2006; Deutsch et al. 2005b). X-ray diffraction patterns of tank sludge material show that large percentages of some sludges are amorphous. One of the fundamental questions to develop a processing baseline becomes:

Question: Can we better characterize the heterogeneous materials in waste tanks and improve our understanding of dissolution/precipitation during retrieval and processing?

Characterization methods for this area are a broad cross-cutting science that impacts each sector of the disposal pathway. Characterizing tank wastes is critical to each of the necessary tasks in the waste disposition pathway, including retrieval and closure of the tanks. The wastes, including both sludge solids and dissolved saltcake, need to be retrieved to the maximum extent practical as part of the closure process, and although water is typically the preferred solvent for removing residual saltcake, acids have been used to augment the sludge dissolution process. In addition, accurate characterization of the tank wastes and residuals is critical to performance assessments for the closure process.

Minerals present in the tank wastes have well-defined major ion compositions; however, trace constituents present in the minerals provide for some variability in composition. The primary contaminants $\left({ }^{99} \mathrm{Tc},{ }^{129} \mathrm{I}, \mathrm{U}, \mathrm{Cr},{ }^{237} \mathrm{~Np}\right)$ in the waste, from a long-term risk to groundwater standpoint, may occur primarily as trace constituents in the solids. Compared to the minerals present in the waste, the 
amorphous compounds have highly variable compositions. For example, analysis of an amorphous Mnoxyhydroxide in Hanford tank C-106 by scanning electron microscopy/energy dispersive spectroscopy showed the presence of $\mathrm{Ca}, \mathrm{Al}, \mathrm{Si}, \mathrm{Fe}, \mathrm{Pb}$, rare earth elements $(\mathrm{Ce}), \mathrm{Cr}, \mathrm{P}$, and $\mathrm{C}$ in addition to $\mathrm{Mn}$ (Deutsch et al. 2005b). Compounding the composition complexity of the tank wastes is the presence of organic compounds in addition to the inorganic solids. Organic extraction solvents and organic complexants were used in some of the chemical separation processes at the facilities, and spent compounds were disposed of in the tanks. The principal extraction solvents were tributyl phosphate and normal paraffinic hydrocarbons. Organic complexants included N-(2-hydroxyethyl) ethylenediaminetetraacetic acid, ethylenediaminetetraacetic acid, and glycolic, citric, and oxalic acids (Allen 1976; Meacham et al. 1996).

The importance of characterizing the tank solids and estimating their reactivity to water and other solvents is due to the need to retrieve as much of these solids as possible from the tanks as part of the closure process so that only small amounts of potentially toxic materials are left behind in the tanks. Water is the preferred solvent for removing residual saltcake, but in some cases, relatively insoluble layers in the saltcake have reduced the efficiency of dissolution and removal of the material. In the case of sludge, water has been used to dissolve solids and suspend insoluble material for removal from tanks by pumping; however, in cases where sludge removal with water was not sufficient, oxalic acid (0.9 M) has been used to augment the process (Bechtold et al. 2003). The selection of appropriate solvents would be enhanced by a better knowledge of the solids that need to be removed from the tanks and their solubilities in various extraction fluids. For a given waste feed, the composition will likely change during the retrieval as the more soluble components are recovered from the tank first, resulting in a question:

Question: Is it possible to more accurately characterize the chemical changes that occur in slurries and solutions in real-time?

A second reason for better characterization of the tank waste and understanding of its reactivity is to develop long-term release models for risk assessments required as part of the closure process. The release of uranium to future infiltrating water entering the tank from a uranium mineral of known solubility may be relatively straightforward; however, the release of trace constituents (such as Tc or I) from minerals or amorphous compounds is not as simple to estimate. Simply determining the mineral that contains the contaminant is a challenge when the bulk concentration of the contaminant may only be a few parts per million. Furthermore, the contaminant may be present in one or more of the heterogeneous, amorphous compounds that do not have a fixed solubility and may release some contaminants preferentially to the general mass of the solid because the contaminant is present in a more soluble subphase. Developing defensible contaminant release models for waste that will remain in the tanks after closure is a major scientific challenge.

\subsection{Long-Term Release}

The methods for treatment and disposal are driven by the performance of the final waste form in the natural environment. Performance expectations are controlled by regulatory, state, local, and stakeholder agreements. Additional challenges are presented by secondary wastes, those generated during operations at the primary treatment facilities. Secondary waste compositions are not as well understood, and therefore disposal paths are poorly defined. At least three waste forms are anticipated based on the current DOE cleanup baseline: residual waste, cementitious, and glass. While this section focuses on 
these three waste forms, there are significant opportunities for basic research to develop transformation approaches that revolutionize these current baselines.

\section{Question: Is it possible to develop alternative immobilization and treatment technologies that mitigate the current issues associated with long-term release?}

Some level of residual waste remaining in the HLW tanks following retrieval is expected. Residual waste includes solids as well as scale on the tank bottoms and walls and is potentially contained in ancillary systems and piping. Understanding the mechanisms associated with the potential release of the associated radionuclide contaminants at low levels to the environment via infiltrating water for many thousands of years following the completion of the retrieval mission is needed. Over this timeframe, some of the inorganic solids in the waste may evolve from less stable amorphous compounds (such as iron oxyhydroxides) to more stable crystalline forms (hematite). The change in solid phases may adversely impact the contaminant release rate, or it might immobilize the contaminant in a less soluble phase and reduce releases to the environment. Some of the relatively unique minerals (such as Dawsonite) present in tank sludge may not be stable over the long-term when exposed to more typical earth surface environments. These minerals may degrade the release of some constituents to solution and the formation of secondary minerals. These changes may have an impact on contaminant release. The organic compounds in the waste will change over time and may form stronger complexing agents for the contaminants. For example, tributyl phosphate degrades to dibutyl phosphate, which is more soluble than tributyl phosphate and may enhance the mobility of metals if stable dibutyl phosphate-metal complexes are formed.

Question: Can we extend our existing kinetic and thermodynamic stability models of minerals and organic complexes over hundreds or even thousands of years?

To fill the void spaces in the tanks following retrieval of tank waste, it is anticipated that they will be filled with a cementitious material to maintain tank integrity and reduce contact with water. Similarly, cementitious materials may be used to stabilize many secondary wastes from the primary treatment facilities. For example, these materials may be a mixture of blast furnace slag, Portland cement, and fly ash. The chemistry of the cementitious material will control the solution composition of water percolating through a breached tank or secondary waste storage facility in the future. As the cement weathers and ages, it is expected that solutions in contact with the material will evolve from that dominated by $\mathrm{Ca}(\mathrm{OH})_{2}$ to $\mathrm{CaCO}_{3}$-dominated solution. The chemical evolution of this leaching solution will impact the leachability of contaminants from residual waste. To evaluate the potential long-term release from secondary waste and tanks closed with cementitious material, it is necessary to estimate the changing composition of the leaching solution for thousands of years and evaluate how this solution will impact the chemical system of the residual waste underlying the cement. These performance assessments include hydrogeological models and corrosion models that predict the stability of the grout matrix and the tank steel liner as well as the integrity of the concrete vault.

The corroding steel microenvironment may produce localized reducing or oxidizing conditions that affect the mobility of contaminants by forming less-soluble solids containing the contaminants. For example, $\mathrm{Tc}(\mathrm{IV})$ and $\mathrm{Cr}(\mathrm{III})$ minerals are less soluble in a reducing environment than $\mathrm{Tc}(\mathrm{VII})$ and $\mathrm{Cr}(\mathrm{VI})$ minerals in an oxidizing environment. Some of these secondary minerals, such as $\mathrm{Cr}(\mathrm{OH})_{3}$, will remain stable as oxidizing conditions become reestablished after complete tank corrosion; however, others, such as $\mathrm{TcO}_{2}$, 
will become soluble in the oxidizing conditions and will release contaminants to the environment. The rate of steel corrosion, the impact of micro-environments, and the solubilities of reactive minerals need to be addressed in the tank chemical system to better model long-term tank integrity.

Question: What is the nature of the solid-water interaction in cementitious materials and associated microenvironments, and how does one predict changes over geologic timescales?

Glass must immobilize hazardous and radioactive components for the extended periods associated with planned geological disposal. As glass reacts with water, several processes occur: ion exchange between the solution and the alkali in the glass, hydration of silica ions in solution, dissolution of hydrated silica, and silica condensation from solution (Grambow and Muller 2001; McGrail et al. 2001; Van Iseghem et al. 2003). Although scientists "....are in general agreement in identifying the important factors that affect the long-term behavior of glass. Alteration and dissolution by ground water are considered the most critical factors..." (Ewing et al. 1996), there is not yet sufficient scientific understanding into how key glass and solution parameters (e.g., composition, radioactive decay, and stress, temperature, and radiation fields) influence the long-term release of contaminants to the environment. At present, kinetic models are based on simple first-order reactions in which orthosilicic acid $\left(\mathrm{H}_{4} \mathrm{SiO}_{4}\right)$ is the only ratelimiting species in solution. The basic mechanisms of glass alteration need further investigation (Ewing et al. 1996). The fundamental question is:

Question: How fast will glass react in the disposal environment? With exceedingly long time scales, how will the various reactions between glass and its surrounding environment progress?

A long history of scientific studies laid the basis of our understanding of this question for nuclear waste and natural glasses, e.g., Rana and Douglas (1961), Douglas and El-Shamy (1967), Pierce et al. (2007), and Yokoyama et al. (2008). However, the multi-phase, multi-process nature of the reactions has impacted predictive capabilities, in particular the connection between glass composition and dissolution. For example, few, if any, studies have successfully made the connection between the current understanding of glass dissolution and the glasses that have been buried since ancient civilizations started producing them nearly 3000 years ago. Advanced simulation techniques that account for uncertainties and changes in chemistry as a function of time will assist in answering these questions. See Ewing et al. (1996) and Peters et al. (2008) for thorough discussions of this need.

\subsection{Corrosion Chemistry}

While awaiting retrieval and treatment, the safe storage of high-level wastes in tanks is maintained through comprehensive structural integrity programs - which include corrosion-control programs, nondestructive evaluations, and fracture-mechanics analyses. The corrosion-control programs were initially designed to protect the tank carbon steel in a long-term storage condition. Under this program, hydroxide and nitrite are the primary corrosion inhibitors. Nitrite is native to the tank waste as a result of the decomposition of nitrate that was added originally as nitric acid from fuel processing operations. Hydroxide in the form of $\mathrm{NaOH}$ is currently added to maintain alkalinity. Since any sodium added to the waste increases the eventual volume of waste that must be immobilized, minimizing these additions shortens the mission and reduces costs. The concentration of hydroxide and nitrite needed to inhibit corrosion was determined through empirical models based on coupon tests. Observed corrosion in the tanks indicates that these models significantly overpredicted corrosion rates. Also, these models are not 
sufficient to predict corrosion at other locations in the tank system, such as the vapor space/liquid-air interface typically occurring under thin film or pseudo-atmospheric conditions that will be discussed later in this document. This presents a fundamental question:

Question: What are the mechanisms governing corrosion of materials in contact with high-salt aqueous systems, and what are the additional effects of radiation on these materials?

\subsection{Foaming and Antifoaming Behavior}

Foaming in HLW is a significant problem in storing and processing these wastes. Previous studies have identified the key role of small insoluble particles in creating particle-stabilized foam lamellae as the fundamental mechanism for foaming in waste slurries (Wasan et al. 2004; Bindal et al. 2001, 2002; Ali et al. 2000; Rossen and Kam 1996). It was determined that small particles that attach to bubbles can inhibit the coalescence of bubbles and create stable foams. This is because the particle surfaces have intermediate or mixed wettability. These studies also determined the major mechanisms of antifoam action in foams stabilized by solid particles. In actual waste slurries, the insoluble sludge particles are a mixture of different chemical species, and each particle species will have different interactions at bubble/liquid interfaces and different interactions at the solid/liquid interface with antifoaming and rheology-modifying chemicals. While the previous studies elucidated key mechanisms, gaps still exist in understanding how specific particles with their unique surface chemistry interact with bubbles and chemical additives. A better understanding of this complex behavior will improve waste processing and improve additives for antifoaming and rheology modification.

Question: What are the mechanisms of complex surface chemistry modification and their impacts on foaming and antifoaming for mixtures of insoluble particle species in concentrated electrolyte solutions? 


\subsection{Coupled Chemical and Physical Processes in Environmental Applications}

Rheological behavior in slurries is dependent on a complex combination of chemical and physical parameters. Ionic strength, $\mathrm{pH}$, zeta potential, solids concentration, surface chemistry, particle shape, particle-size distribution, temperature history, shear history, and time all affect the flow behavior of the slurry. These parameters change slowly during storage and dramatically during waste retrieval and processing. In a typical retrieval process, the initial tank farm slurry is retrieved with water jets and sent to the waste processing facility. The retrieved slurry feed will then be processed through several unit operations involving separations of radionuclides and non-radioactive waste components. Changes including $\mathrm{pH}$, dissolved salt content, solids volume fraction, particle size, and solid/liquid chemistry occur during separations and conversion to the final waste form. These physiochemical changes shape the interparticle colloidal forces. This section discusses several fundamental science challenges associated with the modeling and better understanding of how these forces are affected by changes in these coupled chemical and physical environments.

\subsection{Rheological Properties of Colloidal Slurry Systems}

The HLW tanks at DOE cleanup sites contain a mixture of solid and liquid phases. The solid phases typically consist of fine metal oxide particles (Wells et al. 2007). The liquid phase is an aqueous solution with a high concentration of dissolved salts. Such solid/liquid systems often possess non-Newtonian rheology or fluid behavior. A non-Newtonian fluid is defined as a material in which the viscosity changes with the degree of shear that the fluid is experiencing (Poloski et al. 2007). Therefore, the fluid does not have a well-defined viscosity that can be used as an input in process design efforts. Often, slurry rheology is a bottleneck in environmental cleanup processes. Controlling slurry rheology to overcome these processing limitations is a significant issue to DOE.

It is well-known that slurry rheology depends on many chemical and physical parameters that change during waste retrieval and processing. These parameters include ionic strength, $\mathrm{pH}$, solids concentration, surface chemistry, particle shape, and particle-size distribution (Zhou et al. 2005). Recent developments in colloid modeling have allowed for the development of mechanistic equations describing how slurry rheology changes with several colloidal variables (Laxton and Berg 2005). These colloidal variables include zeta potential, inverse Debye length, and the Hamaker constant (Larson 1999). However, the models were developed for ideal, simple systems. Extending this knowledge to complex systems requires an understanding of the interactions between bulk chemical and physical properties of the slurry and the colloid-level variables that govern rheology. Guo et al. (2003) make the following statement about this approach for modeling rheology with colloidal interactions:

A feature of the above equation is to correlate the normalized shear yield stress with surface chemistry independently of the structural properties of particles. Thus, all normalized data of yield stress for the suspensions with a variety of solids concentrations should collapse onto a single master curve in a plot against the square of zeta potential or $\mathrm{pH}$. 
Several DOE contractors have taken the approach of obtaining a master curve relating weight percent solids to slurry "viscosity" and applying it to an entire process flowsheet. Since the colloidal parameters discussed above are not considered in this approach and they are expected to change throughout the lifecycle of a waste treatment process, one can also expect to observe variability in the slurry rheology master-curve predictions. Understanding and considering how the major variables in the Derjaguin, Landau, Verwey, and Overbeek (DLVO) theory, such as zeta potential, inverse Debye length, and Hamaker constant, vary under nuclear waste processing conditions is essential to extending our understanding of such systems. This is a step in realizing the goal of obtaining a master curve for nuclear waste slurry rheology.

Understanding how the major variables in colloid modeling theory, such as zeta potential, inverse Debye length, and Hamaker constant, vary under different chemical and physical environments for complex fluids needs to be improved. Experimental studies should be focused on varying chemical and physical properties and understanding the effect on colloidal properties. These experimental data will create the foundation for a master curve relating nuclear waste slurry rheology to chemical and physical properties. With this approach, the following question can be addressed:

Question: Can we expand our current fundamental models of colloidal behavior to predict variability and dynamics in more complex chemical and physical systems?

\subsection{Interaction of Colloidal Properties and Fluid Dynamics}

Colloidal variables govern the interaction potential between particles. The interparticle attractive forces generated by this potential often result in flocculation or coagulation. In flowing systems, the flocs can be broken down, resulting in varying rheological structure under differing flow conditions (Marchisio and Fox 2005). The distribution of flocs that result from the shearing forces present in flowing systems results in a system of "flow units" that govern the observed viscosity of the slurry (Bibik 1981). The size, shape, and distribution of the flow units can be described as the "rheological structure" of the system. Recent advances in computational fluid dynamics techniques now allow for the possibility of coupling colloidal force models with the Navier Stokes equations. The aggregate size distribution can be determined by solving the population balance equation (PBE) at every computational node in the domain of interest. The Direct Quadrature Method of Moments (DQMOM) represents the evolution of the aggregate size distribution using a small number of scalar values (Poloski et al. 2006). This allows for the possibility of modeling rheological structure under different flow conditions.

Modern rheometers are now coupling microscopy and light-scattering techniques with sensitive torque and speed sensors (Di Cola et al. 2007). This allows scientists to obtain quantitative data on rheological structure and the resulting fluid rheology under a wide range of shear environments. The breakdown of rheological structure under high shear conditions often results in a "shear-thinning" flow curve where the viscosity of the slurry appears to thin or lessen with increasing shear rate. Understanding this interaction between rheological structure and fluid rheology can allow for fundamental correlations between these parameters to be obtained. If these correlations are used in the computational fluid dynamics framework discussed above, the following question can be addressed:

Question: Can advanced computational fluid dynamics techniques predict rheological structure and the resulting rheological behavior of complex fluids under varying flow conditions? 
The topics discussed above deal with flow under steady-state conditions. However, under transient conditions, the rheological structure of colloidal slurry will tend dynamically towards a steady-state value. This is due to the floc size with shape distributions changing with time (Llorens et al. 2007). Flocs can either break down with increasing shear or increase in size with decreasing shear. The resulting change in rheological properties as a function of time is called thixotropy. The combination of thixotropic fluids and unsteady shear conditions is common in many environmental applications, for example, the application of pulse jet mixers on Hanford HLW tank sludge (Meyer and Etchells 2007).

Several rheological models, including the Moore and Cross equations (Llorens et al. 2007), use a differential equation to model how the rheological structure varies with shear rate and time. The coefficients in this differential equation are found empirically through experimental data. This process requires a well-characterized fluid under a wide range of chemical and shear conditions. As discussed above, modern rheometers have the potential of directly measuring rheological structure as a function of time under a wide range of flow environments. If experimental correlations are obtained for the kinetic behavior of the rheological structure, computational fluid-dynamics techniques can potentially model the resulting transient rheological behavior. This leads to the question:

Question: Can the thixotropic rheological properties be predicted through a combination of rheological structure modeling and computational fluid dynamics under transient conditions?

Conversely, under quiescent conditions, the long-range forces begin to dominate, and the solid particles begin to agglomerate and then consolidate. During this process, the rheological structure and solids concentration increase until solid-like behavior is observed. For these materials, a threshold stress or yield stress needs to be overcome to allow the slurry to flow, and it defines the transition from solid-like to fluid-like behavior.

Current mechanistic equations for the yield stress based on DLVO theory predict a dependence on the inverse relationship between particle size and yield stress. However, many experiments have demonstrated that yield stress is proportional to the inverse square of particle size. On this topic, Zhou et al. (2001) state that "Although the perplexing question of why the additional inverse size dependence observed is open for discussion, it is not likely to come from the force dependence (which is well predicted by traditional DLVO equations)."

Yield stress is an important engineering parameter for environmental cleanup processes. Yield stress defines the stress needed for sludge mobilization and defines the size of gas bubbles that can be retained. By understanding the dynamics of rheological structure and colloid properties, the following question can be addressed:

Question: Can the yield stress of slurries be predicted through a combination of dynamic rheological structure models and colloidal properties?

\subsection{Environmental Process Applications}

The rheological properties such as yield stress, shear-thinning, and thixotropy have a profound influence on slurry mobilization, mixing, gas-holdup, and solids suspension in vessels and pipelines. However, 
conventional design equations for these processes are based upon Newtonian viscosities. Critical velocities for pipeline transport of particles are only defined for Newtonian carrier fluids. Likewise, just suspended velocities for solids suspension in mixing vessels are also primarily defined for Newtonian fluids (Zwietering 1958).

Current testing of process applications involves physically scaling down the system and experimental testing with non-Newtonian simulants. Testing several process designs or geometries with different simulants is time consuming and expensive. Interpreting experimental results is difficult and often extremely limited due to instrumentation requirements. Developing the computational fluid dynamics tool discussed above, which couples colloidal variables with Navier Stokes equations, will allow flow in complex process applications with complex fluids to be simulated. This will allow for easier interpretation of experimental results and rapid testing of various design options with different rheological fluids. Such a tool needs to be benchmarked against existing experimental data for complex process applications with complex fluids. The benchmarking effort should be designed to answer the following question:

Question: Can advanced computational fluid dynamics techniques assist in predicting the performance of complex processing equipment with thixotropic non-Newtonian fluids?

\subsection{Bubble Formation}

Bubbles of hydrogen gas are well known to be retained by radioactive waste slurries, and this potential for retention of hydrogen gas is a safety hazard that must be managed. The size of the bubbles is known to play an important role in how they are retained and released from waste in underground storage tanks and in process vessels (Gauglitz et al. 1995, 1996; Gauglitz and Terrones 2002; Rassat et al. 1997, 1998; Stewart et al. 1996; Bredt et al. 1995; Bredt and Tingey 1996). A largely unexplored fundamental issue is how bubble aging changes the size distribution of the bubbles in complex multi-phase slurries that exhibit a yield stress. Ostwald ripening, as it is often called, refers to how surface tension causes smaller bubbles to shrink and larger bubbles to grow at their expense (Shaw 1980). The capillary force from surface tension increases the pressure in a bubble as the bubble size decreases. As a result of the pressure difference between two bubbles of different sizes, the gas in the smaller bubbles dissolves into the surrounding fluid, diffuses to a larger bubble, and then partitions into the larger bubble, causing it to grow. The result is a bubble size distribution that shifts to larger sizes over time. If the bubbles are in a slurry that has a yield stress, however, the yield stress inhibits the shrinking and growing of the bubbles. While Ostwald ripening in Newtonian fluids is well known, the role of the yield stress for bubbles in multi-phase slurries has not been explored and is a fundamental issue that needs to be quantified to understand the retention and release of hydrogen gas bubbles.

Question: What is the nature of bubble slurry interactions that influence the distribution of bubble sizes in multiphase slurries?

\subsection{Gas Retention and Bubble Dynamics}

Previous studies have empirically determined the macroscopic properties that result in gas retention and release in slurries, and the yield stress and particle size of the slurry are two important parameters (Gauglitz et al. 1996, 1995; Rassat et al. 1998, 1997). However, the micro-structural properties affecting gas retention and release are still not well understood. These include particle wettability, surface tension, 
and parameters describing the behavior of a slurry as it yields. While studies have considered the quasistatic (slow) deformation of bubbles in yield stress materials (Terrones and Gauglitz 2003), the dynamic behavior at the microstructural level has not been explored. For example, the rapid release of gas bubbles via a bubble cascade mechanism is a poorly understood phenomenon that may be a significant issue for future waste retrieval and mixing activities. It is theorized that a bubble cascade occurs when a retained bubble that was initially stagnant in a waste slurry with a yield stress begins to rise, and its motion interacts with bubbles in its path, shears adjacent waste, and enables a second bubble to begin rising. These two bubbles further interact with additional bubbles and shear more adjacent waste, leading to a cascading effect of rising bubbles. While this bubble release behavior has been observed in some limiting situations, the underlying microstructural mechanisms have not been studied and quantified. This leads to the question:

Question: What is the nature of bubble retention and release on the microscopic level, and what are the effects of slurry composition?

\subsection{Cold-Cap Reaction Mechanisms}

The successful treatment of nuclear wastes depends on an efficient melting process. Aqueous slurries with waste solids and glass-forming chemicals are fed to the melt pool to form a cold-cap. Heat from the molten glass dries the slurry and facilitates the reaction of the compounds in the cold-cap. A series of reactions in the liquid, solid, and gas phase progresses until the material forms a molten silicate melt that is poured from the melter into a canister where it solidifies into the final glass waste form. The rate of processing is dictated by the chemical and heat transport across the melt/cold-cap boundary. It is difficult to simulate a real cold-cap in its entire complexity in the laboratory. Cold-cap measurements in a melter are limited. Recently, real-time temperature and temperature distributions of a cold-cap have been measured in a test melter (Sundaram et al. 2002). Additional science is required to define the reactions in the cold cap as well as to understand the associated kinetics and thermodynamics. The rates of reactions need to be coupled to the transport of heat, reactants, and products in the cold-cap to answer the fundamental question:

Question: Can cold-cap behavior and reactions be predicted with broadly varying chemical compositions through a better fundamental understanding of the interplay between reactions of solid, liquid, and gas phases? 


\subsection{Complex Solution Phase Phenomena in HLW Processing}

Unraveling and predicting complex solution phase phenomena in both aqueous solutions and liquid glasses has been, and will continue to be, recognized as of prime importance in HLW processing. Such solution phase phenomena are fundamental to controlling the stability of the waste glasses, retrieving tank solutions, determining the leaching of tank sludges, and determining the long-term stability and corrosion of the waste tanks, and they are key to developing separation strategies for radioactive and nonradioactive components. This section presents a brief summary of the progress to date in the area of solution phase phenomena and the future scientific challenges.

\subsection{Role of Aqueous Solution Phase Phenomena}

Because of the near ubiquitous presence of water in virtually all HLW processing streams, the chemical behavior of dissolved solutes in aqueous solution has been a focus of process engineers and scientists, starting with the Manhattan Project and continuing today. During this time, much of the fundamental equilibrium chemistry of actinide elements, fission products, and many non-radioactive components has been elucidated, and we now know a great deal about the chemical behavior of these species in aqueous solutions over extended ranges of solution composition and temperature. This fundamental knowledge has, over the past two decades, been summarized in several thermodynamic data reviews and incorporated into predictive chemical models that have been used at all DOE HLW storage sites to analyze a wide range of issues. These issues range from HLW processing from predictions of the dissolution of waste sludges to the removal of radionuclides from process streams to line plugging in waste transfer lines. The challenge now is to extend this successful equilibrium-based approach to non-equilibrium reactions and more extreme conditions in solvent properties.

In this regard, it will be essential to address fundamental questions on the nature of solution phase reactivity.

Question: Can we predict the thermodynamics of concentrated electrolyte and mixed-solventelectrolyte systems to very high concentrations?

Over the past two decades, much progress has been made in our ability to model the thermodynamics of aqueous solutions, including actinide species (Grenthe et al. 1992; Silva et al. 1995; Lemire et al. 2001; Guillaumont et al. 2003). In addition, there exist extensive databases of modeling parameters for semiempirical activity coefficient models such as those of Pitzer and co-workers (Felmy and Rai 1999) and the Specific Interaction Theory (SIT). All of these expressions have limitations in the total ionic strength over which they are applicable, resulting in numerous "extended theories," and none are applicable for mixed solvent-electrolyte solutions. Fortunately, there has been significant progress in developing mixedsolvent-electrolyte (MSE) models, including the ability to include complex chemical species within the modeling framework (Wang et al. 2002, 2004a, 2006; Anderko et al. 2002), as well as transport and other properties (Wang et al. 2004b). In addition, these MSE models have been found to be capable of modeling the aqueous thermodynamic of the mixed solvents to the pure solvent limits and to exceptionally high ionic strength (i.e., the fused salt limit). New thermodynamic data needs to be developed to extend these approaches to include the range of solutes and extraction systems needed to predict the efficiency of waste tank evaporators, the drying of solutions on tank walls (and hence tank corrosion), and the development of more efficient separation strategies. 
Question: How do changes in ion solvation and chemical speciation in concentrated electrolytes impact water activities and exchange rates and hence the kinetics of precipitate formation or dissolution?

One of the fundamental rate-limiting steps in solid phase precipitation is the necessity for the chemical species in the aqueous phase to transform from their solvated or complexed form in solution into the coordination environment that can be accommodated in the solid phase. This transformation may require a change in the coordination environment [e.g., tetrahedrally coordinated $\mathrm{Al}(\mathrm{OH})_{4}{ }^{-}$in aqueous solution to octahedrally coordinated $\mathrm{Al}$ (III) in the solid phase], the elimination of waters of hydration [e.g., $\mathrm{Ca}\left(\mathrm{H}_{2} \mathrm{O}\right)_{8}{ }^{2+}$ in solution to $\mathrm{Ca}(\mathrm{OH})_{2}$ in the solid] and/or the elimination or attachment of ligands to the metal ion [e.g., $\mathrm{Sr}(\mathrm{EDTA})^{2-}$ in aqueous solution to $\mathrm{SrCO}_{3}(\mathrm{c})$ ]. Currently, kinetic models of solid phase dissolution/precipitation take into account these changes in solution conditions only by calculating the degree of saturation (distance from equilibrium). These kinetic approaches need to be extended to include the impact of the changing state of the solution changes in ion solvation and chemical speciation on the rate constants for dissolution/precipitation to develop robust models of the dynamics of precipitate formation and dissolution. These changes in the chemical form of the species in solution can have a dramatic effect on the rates of precipitate formation and dissolution in waste tank supernatants. These concepts are also important to separation processes. For example, in ion exchange and extraction processes, considerable changes in ion solvation can occur as the ions transfer from one phase to the other phase. In high-ionic-strength solutions, the reduced concentration of "free" molecules may reduce ion exchange reaction rates that depend on solvation, but could increase extraction rates as a result of increased ion pairing.

Legacy high-level nuclear wastes are stored in large underground carbon steel tanks. These tanks generally have active ventilation systems to prevent the buildup of flammable vapor gases, such as hydrogen, which are produced by radiolysis of water. Radiolysis of the solutions and dissolved organics also produce a variety of volatile nitrogen-containing compounds that can impact the corrosion of the tank headspace. Chemically derived volatile compounds can also be produced during the long storage periods of the waste. These compounds can impact the corrosion of the tank headspace and present safety risks in tank farm operations. Examples of chemically derived volatile compounds include low-molecular-weight organics, such as trimethylamine, organomercury compounds, such as dimethlylmercury, and nitrogen compounds, such as ammonia and nitrous oxide. The formation and release of volatile organics increases the burden on the ventilation system to maintain a non-flammable composition in the tank vapor space and reduce possible tank headspace corrosion. The organomercury compounds are highly toxic and thus represent an increased concern for exposure to onsite and offsite personnel.

Question: How do we predict the evolution of vapor phase species from tank supernatants resulting from radiolysis and changing tank chemistry?

The release of these gases from the strongly alkaline waste solutions shows non-linear behavior, indicating stronger interactions between the volatile and non-volatile components in the waste solutions. Consequently, predicting volatile releases is generally poor. This non-ideal solution behavior is likely due to both the high ionic strength of the waste solution and the presence of micron and sub-micron size transition metal hydroxides and hydrous metal oxides produced after adding sodium hydroxide to the acidic waste solutions. The effects of high ionic strength of the waste solutions coupled with the variable 
composition of both the saltcake and the sludge solids limits a detailed understanding of the many steps involved in the production and release of volatile organic compounds. Consequently, continued operation of the tank farms requires a better understanding of the above phenomena, which can accelerate tank headspace corrosion and the release of volatile substances. A detailed mechanistic and predictive understanding is needed of the processes that result in the generation of these volatile compounds and their release mechanisms from the supernatant.

\subsection{Nature of Glassy Materials}

The U.S. and international communities rely primarily on glass as a waste form for their most highly radioactive nuclear wastes. These glasses have many advantages over other crystalline waste forms. The ability to predict the performance of glass under extreme conditions and over very long time scales depends on a clear understanding of the nature of the glassy state. The fundamental question to ask was stated in Science as one of the most significant unanswered questions of science (Kennedy et al. 2005):

Question: What is the nature of the glassy state? Molecules in a glass are arranged much like those in liquids but are more tightly packed. Where and why does liquid end and glass begin?

The answer to this question has eluded scientists because of the complex nature of glass and the glass transition. Glass lacks long-range order; therefore, the energy distributions are not periodic. Glasses are traditionally characterized after the liquid has cooled to ambient temperatures. However, there is ample evidence that the chemistry in the liquid state is fundamental to understanding how metal oxides, alkali oxides, alkaline earth oxides, and non-metal oxides (e.g., boron, sulfur) are incorporated into the glass matrix. This complex chemistry is not understood, but has been suggested by several authors (Li et al. 2004, 2005; Zhang et al. 2001). Current modeling and experimental techniques are limited, e.g., model cooling vs. real cooling rates and the ability to model and measure the dynamics of solidification in realtime. In addition, glass structural measurements (e.g., low-angle X-rays, extended X-ray absorption fine structure, multinuclear NMR) have not been rigorously adapted and used for complex glasses. Advanced modeling and experimental techniques are required to ultimately answer this question. The fundamental question must first be answered for simple glass systems. To be useful in making glasses for nuclear waste management, these techniques must be applied to glasses of increasing complexity, such as oxide waste glasses containing up to 40 chemical elements. For complex glasses, advanced statistical techniques will have to developed and applied for incorporating glass-structure-property correlations. 


\subsection{Chemical Recognition Phenomena in Environmental Applications}

Lehn originally defined recognition in terms of selective binding connected with some purpose (Lehn 1973). In the present context, the motivating purposes entail the core environmental needs for monitoring and analysis or for decontamination of waste, equipment, buildings, soil, groundwater, etc. This section discusses the role of chemical recognition, the design of new reagents and materials, chemical recognition in separations, sensing and analytical methods, interactions at solid interfaces, and the recognition of specific contaminant species. Significant fundamental questions have been identified for research inquiry.

\subsection{Role of Chemical Recognition}

Binding a guest ion or molecule enables a separation or detection, and selectivity becomes the most important characteristic of the binding interaction. Since selectivity results from differences in binding affinity, perhaps the most fundamental question for research for environmental monitoring and cleanup then becomes:

Question: What are the fundamental interactions that maximize differences in binding affinity and thereby maximize the selectivity of binding phenomena?

As for any chemical process, to understand binding sufficiently to be able to control it for our purposes requires an understanding of the initial state of the system as well as the final state in which the binding has occurred. This understanding must take into account the complexities of the matrix environment and its effect on the process, as we have discussed in the sections on complex fluid-phase phenomena and the structure and dynamics of materials and interfaces. Accordingly, binding can occur in homogeneous solution, where a ligand, for example, complexes a metal ion, or it can occur at an interface, where a metal ion is adsorbed, for example, onto the surface of a membrane. It also can occur in the interior of a solid, which could be an ion-exchanger or precipitated crystals. It can even occur in the gas phase or in biological systems. To be useful, the chemical interactions engaging the bound species must be favorable compared with its initial or unbound state. Very often, the initial state of interest is an aqueous or aqueous-soluble medium, as in groundwater or the high-level salt wastes stored at Hanford and the Savannah River Site. However, some of the more difficult problems of decontamination can entail the solid surfaces of equipment, building materials, or soils (see below). Questions regarding the nature of the contaminant species in their starting environments have been discussed in other sections of this report, but it is taken as implicit in the design of reagents and materials for selective binding of contaminants that the initial state of the contaminant is first understood. It may be reiterated here:

Question: What is the nature of the interactions of the components of matrix environments with target species of interest for separations and sensing?

In the context of this discussion, the binding agent for a target species is referred to as a receptor or host, and it will be broadly considered here to mean molecular as well as solid-phase materials. In the vein of host-guest chemistry, the target species, referred to as a guest ion or molecule, can be a contaminant of interest, most often a radionuclide such as ${ }^{99} \mathrm{Tc}$ or ${ }^{137} \mathrm{Cs}$; a toxic metal, such as beryllium, mercury, or 
lead; a species that interferes with processing, such as sulfate in vitrification; or otherwise harmless species that contribute to waste volume, such as sodium and aluminum. A receptor structure whose shape and electronic characteristics are complementary to those of a guest species will bind selectively to the guest species if the binding interaction is sufficiently strong in the medium in which it occurs. The binding interactions from the receptor or host originate from collections of donor atoms held in space by a superstructure of linking groups. The superstructure may be a molecular framework constructed of all covalent bonds, but it can also involve self-assembled frameworks constructed partly from weak bonds, such as coordinative interactions, H-bonds, pi-pi stacking, and the like. If the target guest species is a cation, the donor atoms will be electron-rich ones, especially oxygen and nitrogen atoms. Likewise, anion receptors consist of an array of electropositive groups, especially hydrogen-bond (H-bond) donors and coordination sites on metal cations. Much of what is known about binding comes from research on coordination chemistry (Wilkenson 1987) and supramolecular chemistry (Lehn et al. 1996). Still, we are not yet at the stage where the thermodynamics of ion binding can be predicted, leading to the fundamental question:

Question: Can the structure of complexes and the thermodynamics of complexation processes involving small donor molecules and ions be predicted in condensed media?

\subsection{Design of New Reagents and Materials}

Appreciating the role of the matrix environment as just discussed, the applicable focus of research in chemical recognition is properly the design of reagents and materials for selective binding of contaminants and functional performance of the formed complex in either a separation or sensing. This goal suggests the fundamental question:

Question: Can molecules and materials be designed to have predictable binding properties for target contaminant species? Can functional attributes be incorporated into the molecular design so that the designed receptors behave predictably in separations or sensing?

The suggestion that molecules can be "designed" itself raises philosophical issues (Jansen and Schön 2006) that will be sidestepped here by noting that human choices in the process of selecting and weighing options and in applying human criteria seem to justify the use of this terminology. However, it may be noted that a comprehensive design process that accurately predicts properties is still not practical and remains a research endeavor of its own (Schmidtchen 2006). The "design" of chemical-recognition agents as currently practiced consists of human creativity enlightened by sound chemical principles and some computations where possible, but relying largely on experimentation involving iterative synthesis and testing. As design by computational methods improves, a major goal will be to reduce or eliminate the iterative experimental process such that preparative routes to hypothetical separation and sensing materials can be identified without resort to trial-and-error synthesis research. In its present state, the synthesis of new materials remains an art. Clearly, to realize the goal of design, the design process should ultimately incorporate synthesis.

Given that receptors consist of donor atoms that can be positioned in space in a complementary way about a guest species, the object of design becomes one of predicting optimal ways to arrange these donor atoms and fix them in space within a framework that serves the dual purposes of binding and either separation or sensing (Hay and Hancock 2001). Principles of supramolecular chemistry have taught that the greatest 
selectivity can be expected when the receptor is most complementary for the guest, and as this verifies optimal interaction, it also maximizes the strength of the interaction (Lehn 1973). If the receptor is sufficiently rigid that it cannot rearrange its structure to accommodate competing species, selectivity is maximized. Rigidity also minimizes the enthalpic and entropic costs to organize the receptor, thereby maximizing the binding strength. The receptor is said to be preorganized (Cram 1988).

At present, computer-aided design techniques for building molecules are being developed to begin addressing such issues (Hay and Firman 2002), but the techniques are in their infancy. Predicting behavior in condensed phases remains impractical, and the designs do not yet incorporate functional aspects such as lipophilicity, which is needed for transport, or transduction, which is needed for sensing. Designing solid-phase materials is an opportunity for research.

\subsection{Chemical Recognition in Separations}

Separation science as unified by Giddings (1991) entails the use of a wide variety of chemical and physical phenomena acting alone or in combination to spatially resolve the components of a mixture. Most often, this means that one component is transported into another phase or retained (as by a filter), leaving behind the other component. In this context, receptor molecules or materials facilitate the transport or retention and additionally make it selective. The types of separations (Ruthven 1997) are too numerous to cover here. Relevant examples include resin ion exchange, inorganic ion exchangers, liquidliquid extraction, membrane transport, ultrafiltration, and selective crystallization, all of which can be used for environmentally related applications. In each case, the receptor must be designed to function in the particular configuration of the technique:

Question: How can receptors be designed to function efficiently in different types of separation systems?

Thus, a crown ether could be designed to bind a particular metal ion, such as $\mathrm{Cs}^{+} \mathrm{or} \mathrm{Sr}^{2+}$, but it would have to be lipophilic and soluble in organic solvents or ionic liquids, for example, to perform a liquidliquid extraction (Moyer 1996). Lipophilic groups can be added to the crown ring, but they can greatly affect binding affinity and selectivity (Dietz et al. 1999), and thus, how to add the seemingly simple lipophilicity very much becomes a design issue. In membrane transport, diffusion becomes an issue, and design must take into account diffusivity of the receptor and its complexes (Chrisstoffels et al. 1999). Crown ethers can also be employed in micelle-enhanced ultrafiltration as in liquid-liquid extraction, but the receptor has to be compatible with micelle formation and binding in such structures. In other applications, crown ethers can be appended to ion-exchange resin backbones or to the surface of inorganic supports, but this requires identifying the proper covalent linking group and considering charge neutrality in the ion separation. Although these examples focus on crown ethers, about which much is known for binding of contaminants of interest, the principles learned apply broadly to other receptors.

Although it was discussed above how a crown ether could be used with modifications in multiple types of separation systems, some receptor materials have no such analogs. These include solid-phase materials such as crystalline silicotitanate (CST), a strong and essentially irreversible receptor for $\mathrm{Cs}^{+}$ion (Miller et al. 1998). In some respects, the environment around the $\mathrm{Cs}^{+}$bound inside CST is very much like a crown ether, but the inorganic framework is unique. Often, such materials are kinetically slow, and 
engineered forms have to be designed that offer the surface area needed for rapid uptake and yet have structural stability.

Separation methods most often require the continuous recycle of the receptor material, which means the material must undergo binding-release cycles. Exceptions include inorganic ion exchangers like CST, which tend to irreversibly bind the target ion, and must be used as the final waste form. When release is needed, it becomes a major aspect of receptor function, as important as the binding aspect. As such, receptors must be designed to efficiently release target species without creating unacceptable volumes of secondary waste.

Another desirable aspect of separation systems is achieving combined selectivity. An ideal decontamination method for environmental applications is one that neatly removes all contaminants in one step. Given that many if not most real contamination problems involve more than one contaminant, it would lead to great savings if the recognition property could be tailored so that any desired selectivity pattern could be "dialed-in" such that multiple contaminants could be removed in a single step.

\subsection{Sensing and Analytical Methods}

For sensing or analytical purposes, a fundamental question arises:

Question: How can reporter groups, such as fluorophores and chromophores, be coupled with binding groups and tethered to surfaces to most efficiently signal binding without interfering with the binding process itself?

Lehn early on conceived of recognition in terms of information storage, whereby binding represented the input of information on the target species that could later be interrogated (Lehn 1973). That means that the receptor has to be equipped with functionality that enables "read out."

In the simplest analytical application, and the one perhaps most often used for measuring contaminant concentration, the receptor material is employed as a separation agent that merely preconcentrates the contaminant for subsequent elution and analysis by instrumental methods (e.g., radiometric counting, inductively coupled plasma, mass spectrometry). An example is the use of extraction chromatography (Dietz 2004), for example, employing a crown ether to preconcentrate ${ }^{90} \mathrm{Sr}$. In such cases, one is interested in high selectivity and a good release mechanism that will accommodate subsequent recovery of the contaminant in a suitable matrix. Some materials can be designed to be "read out" directly, perhaps by radiometric counting, thereby obviating the necessity of an elution step.

For remote, unattended, or long-term monitoring purposes, sensors are needed that can translate the binding event to a readable signal. Transduction principles vary widely, including, for example, fluorescence, absorbance, scintillation, cantilever deformation, and interfacial potential. As in the case of separation, the molecular structure of the receptor must be tailored so that the binding leads to the desired response, and the reporter function, such as fluorophores and chromophores, can interact strongly with the binding function (Johnson 2003). Research is also needed to understand the effect of tethering of receptor molecules to surfaces on binding properties because many examples arise wherein the receptors must be tethered to a surface (Flinck 2000). 


\subsection{Interactions at Solid Interfaces}

Recognition at solid surfaces can be viewed as a matrix phenomenon or an intended separation or sensing. As mentioned above, the contaminants of interest may be already tightly bound to a surface or embedded in a solid material, and the object of the decontamination will be to disrupt the binding and possibly replace it with that of a separating agent. The problem of contaminants on solid surfaces is especially difficult, justifying the following question:

Question: What is the structural nature of contaminant species on or in complex solid materials, such as building materials, soils, and metals, and what chemistry can be applicable to its forced release?

Significant budget is scheduled to be expended in deactivation and decommissioning of old DOE facilities in the coming years, including closure of HLW storage tanks, buried transfer lines, and treatment facilities. Large volumes of contaminated materials will be need to be stabilized and sent to burial grounds. Thus, opportunities for cost savings and environmental stewardship can be expected through better decontamination methods to reduce source terms. This will require understanding how contaminants are fixed onto the surfaces of tank liners, piping, equipment, hot-cell walls, fume hoods, floors, etc. From a fundamental perspective, this task is daunting because of the complexity of the solid matrices, involving multiple phases of a widely different nature, and adsorption processes for all contaminants of interest must be understood for all phases. Some phases exhibit remarkable affinity for ions, such as certain aluminosilicate phases in concrete for $\mathrm{Cs}^{+}$, making decontamination very difficult.

From the perspective of engineered sorbent materials for decontamination or sensing applications, it is the object to design solid-phase materials that exhibit chemical recognition. One may approach this problem by tethering receptor molecules to solid supports (e.g., silica, titania, polymers), invoking questions suggested above. Even more challenging is the design of new porous materials in which the surface or internal structure itself offers cavities that can selectively bind target ions (see above).

\subsection{Recognition of Specific Contaminant Species}

Certain contaminants in waste and decontamination applications within the DOE complex are so commonly encountered that their chemistry becomes of specific interest in fundamental investigations related to separations and sensing. These include, for example, cesium $\left({ }^{135} \mathrm{Cs},{ }^{137} \mathrm{Cs}\right)$ and strontium $\left({ }^{90} \mathrm{Sr}\right)$, both of which are high-yield fission products that are abundant contaminants and highly soluble and mobile; ${ }^{99} \mathrm{Tc}$, another high-yield fission product but with a long half-life and high mobility; uranium and the actinides, especially $\mathrm{Np}, \mathrm{Pu}$, and $\mathrm{Am}$; activation products, especially ${ }^{60} \mathrm{Co}$; and toxic metals, such as $\mathrm{Be}, \mathrm{Hg}, \mathrm{Cr}$, and $\mathrm{Pb}$. As it is clear that the design of recognition agents must start with an understanding of the properties of the contaminants, one may state the initial question in any problem investigation:

Question: What is the chemical speciation and bonding preferences of a contaminant of interest in its matrix, including influences of shape and H-Bonding?

One must also understand, with the help of site managers and regulators, what is the goal of the separation and monitoring and desired end state for the contaminant. Although these and other issues are not relevant to fundamental science, they do serve to narrow choices of systems to study so that the end result of research has the greatest chance for impact. 
Traditionally, most approaches to chemical recognition of contaminants have focused on cations such as $\mathrm{Cs}^{+}$and $\mathrm{Sr}^{2+}$, employing classical coordination chemistry (Wilkenson 1987), perhaps upgraded with more modern computational methods (Hay 2001, 2002) and advances in synthesis of multidentate ligands, such as calixarenes (Gutsche 1998). While there is much chemical knowledge here to draw from, optimal ligands with the desired functional properties still have not been found. Recognition approaches typically must discriminate based on cation properties such as ionic radius, softness, charge, and nonspherical coordination (ligand-field stabilization effects). Shape is normally not a criterion, as most cations of interest are monoatomic; a notable exception is the class of actinyl ions, like uranyl $\left(\mathrm{UO}_{2}{ }^{2+}\right)$.

Many contaminants of interest are anions (Lumetta 2004). A prime example is ${ }^{99} \mathrm{TcO}_{4}^{-}$, the ubiquitous form of technetium in wastes (though some reduced forms are present in certain complexant wastes) and environmental media. Chemical recognition approaches to environmentally relevant anions have been discussed (Moyer et al. 2006) and involve different chemical challenges, among them the fact that, except for the halides, anions are multi-atomic species and thus have shapes, introducing the necessity for shape recognition. As well, given that anion binding is much less developed than cation binding, the groundwork is still being laid regarding how they interact with electropositive groups, especially by H-bonding (Bowman-James 2005).

Finally, a few remarks may be made about the need for chemical recognition and its place as related to certain contaminants. Some separations and sensing chemistries are easy, as given to us in nature's ubiquitous selectivity patterns. For cations, well-known persistent selectivity patterns include the IrvingWilliams order for divalent first-row transition metals (Irving and Williams 1948) for which binding affinity is strongly influenced by the splitting of the unfilled $3 \mathrm{~d}$ orbitals; this order strongly favors $\mathrm{Cu}^{2+}$ among competing transition metal cations. One may conclude that, supposing there was a problem involving copper separation, research would not need to focus on the question of selectivity, as it is easy to obtain with simple, known ligand systems, but rather more research attention needs to address questions related to function. Persistent selectivity orders for cations also include the solvation bias toward transfer of large, charge-diffused alkali metal cations from water to organic solvents, which thus favors $\mathrm{Cs}^{+}$over the smaller competing ions $\mathrm{Na}^{+}$and $\mathrm{K}^{+}$prevalent in DOE wastes (Moyer 1997). For anions, the same type of bias, but this time favoring charge-diffused anions like $\mathrm{TcO}_{4}{ }^{-}$, gives rise to a persistent ordering of anions in anion separation, referred to as the Hofmeister bias (Moyer 2006). These solvation effects mean that no receptor is needed to obtain the desired selectivity for two common contaminants, $\mathrm{Cs}^{+}$and $\mathrm{TcO}_{4}{ }^{-}$, as simple liquid-liquid ion exchange suffices well to obtain high selectivity over competing ions. In fact, using receptors in these cases tends to decrease selectivity! Although no receptor is needed when solvation bias can be exploited, solvation in itself represents a form of recognition, and thus a lesson here is that recognition need not automatically imply the use of engineered receptors. Nevertheless, properly designed receptors can fulfill needs regarding function that cannot be fulfilled with ion exchange, and for such a reason, a calixarene-based extraction system has been found to work well for scaled-up separation of $\mathrm{Cs}^{+}$from alkaline HLW (Moyer et al. 2005). It is clear, then, that research on recognition as pertains to DOE environmental applications should be focused on questions that are not well understood or that do not have currently good prototype embodiments.

\subsection{Conclusions on Application of Chemical Recognition}

Aspects of chemical recognition as it applies to DOE environmental problems have been reviewed from a broad perspective, serving to identify questions that must be addressed for long-term transformational 
progress. Chemical recognition implies binding and function. Binding entails a selective chemical interaction with a contaminant, resulting in the formation of a complex or transfer of the contaminant to an interface or another phase. Function refers to the environmental purpose of separation (decontamination) or sensing. Binding is a ubiquitous phenomenon regarding contaminants of interest, as these are usually "bound" already in some manner in their contaminated matrices, and most separation or sensing approaches involve some type of binding phenomenon put to work by design. Questions for fundamental research may address binding and function separately to some extent, but generally, the two must be dealt with as coupled phenomena. Often, chemical recognition implies the use of receptors, either known or developed by design as a research objective, but receptors are often not needed. In general, greater understanding of these aspects of chemical recognition can be expected to produce major advances in addressing DOE environmental problems. 


\subsection{Conclusion}

This paper presents an initial attempt to frame fundamental questions of importance for reducing technical risk in EM's long-term mission. As with all areas of fundamental research, this requires ongoing discussion as new discoveries are made, and new challenges are encountered. The authors encourage feedback from our colleagues in the community of scientists and engineers interested in nuclear chemistry, materials science, and associated fields. ${ }^{\text {(a) }}$ We look forward to an active dialogue on these important questions and others that may be posed. As such, the final conclusion to this paper is yet to be written.

(a) The authors would like to thank Albert Wagner and Diane Graziano at Argonne National Laboratory for their review and valuable comments received during the preparation of this paper. 


\subsection{References}

Ali SA, PA Gauglitz, and WR Rossen. 2000. "Stability of Solids-Coated Liquid Layers between Bubbles." Industrial and Engineering Chemistry Research 39(8):2742-2745.

Allen GK. 1976. Estimated Inventory of Chemicals Added to Underground Waste Tanks, 1944 to 1975. ARH-CD-6108, Atlantic Richfield Hanford Company, Richland, Washington.

Anderko A, P Wang, and M Rafal. 2002. "Electrolyte Solutions: From Thermodynamic and Transport Property Models to the Simulation of Industrial Processes." Fluid Phase Equilibria 194-197:123-142.

Bechtold DB, GA Cooke, DL Herting, JC Person, RS Viswanath, and RW Warrant. 2003. Laboratory Testing of Oxalic Acid Dissolution of Tank 241-C-106 Sludge. RPP-17158, Rev. 0, Fluor Hanford, Richland, Washington.

Bibik EE. 1981. Rheology of Disperse Systems. Leningradsky Universitet, Leningrad.

Bindal SK, AD Nikolov, DT Wasan, DP Lambert, and DC Koopman. 2001. "Foaming in Simulated Radioactive Waste.” Journal of Environmental Science \& Technology 35(19):3941-3947.

Bindal SK, G Sethumadhavan, AD Nikolov, and DT Wasan. 2002. "Foaming Mechanisms in Surfactant Free Particle Suspensions." AIChE Journal 48(10):2307-2314.

Bowman-James K. 2005. "Alfred Werner Revisited: The Coordination Chemistry of Anions." Accounts of Chemical Research 38(8):671-678.

Bredt PR, and SM Tingey. 1996. The Effect of Dilution on the Gas Retention Behavior of Tank 241-SY103 Waste. PNNL-10893, Pacific Northwest National Laboratory, Richland, Washington.

Bredt PR, SM Tingey, and EH Shade. 1995. The Effect of Dilution on the Gas Retention Behavior of Tank 241-SY-101 Waste. PNL-10781, Pacific Northwest Laboratory, Richland, Washington.

Chrisstoffels LAJ, F de Jong, DN Reinhoudt, S Sivelli, L Gazzola, A Casnati, and R Ungaro. 1999. "Facilitated Transport of Hydrophilic Salts by Mixtures of Anion and Cation Carriers and by Ditopic Carriers." Journal of the American Chemical Society 121(43):10142-10151.

Cram DJ. 1988. "The Design of Molecular Hosts, Guests, and Their Complexes." Journal of Inclusion Phenomena 6(4):397-413.

Deutsch WJ, KM Krupka, KJ Cantrell, CF Brown, MJ Lindberg, HT Schaef, SM Heald, BW Arey, and RK Kukkadapu. 2005a. Advances in Geochemical Testing of Key Contaminants in Residual Hanford Tank Waste. PNNL-15372, Pacific Northwest National Laboratory, Richland, Washington.

Deutsch WJ, KM. Krupka, MJ Lindberg, KJ Cantrell, CF Brown, and HT Schaef. 2005b. Hanford Tank 241-C-106: Residual Waste Contaminant Release Model and Supporting Data. PNNL-15187, Pacific Northwest National Laboratory, Richland, Washington. 
Di Cola E, TA Waigh, and RH Colby. 2007. "Dynamic Light Scattering and Rheology Studies of Aqueous Solutions of Amphiphilic Sodium Maleate Containing Copolymers." Journal of Polymer Science Part B: Polymer Physics 45(7):774-785.

Dietz ML. 2004. "Recent Progress in the Development of Extraction Chromatographic Methods for Radionuclide Separation and Preconcentration.” In: Radioanalytical Methods in Interdisciplinary Research: Fundamentals in Cutting-Edge Applications; CA Laue and KL Nash, Eds. American Chemical Society: Washington, D.C., ACS Symposium Series 868:161-176.

Dietz ML, AH Bond, M Clapper, and JW Finch. 1999. "Isomer Effects in the Extraction of Metal Ions from Acidic Nitrate Media by Dicyclohexano-18-Crown-6." Radiochimica Acta 85(3-4):119-129.

DOE (see U.S. Department of Energy)

Douglas RW, and TM El-Shamy. 1967. "Reactions of Glasses with Aqueous Solutions." Journal of the American Ceramic Society 50:1-8.

Ewing RC, JF Ahearne, RH Doremus, A Navrotsky, JC Petit, and RG Wymer. 1996. Glass as a Waste Form and Vitrification Technology. National Academies Press, Washington, D.C.

Felmy AR and D Rai. 1999. “Application of Pitzer's Equations for Modeling the Aqueous Thermodynamics of Actinide Species: A Review." (Special memorial Edition in honor of Professor Kenneth Pitzer.) Journal of Solution Chemistry 28(5):533-553.

Gauglitz PA, and G Terrones. 2002. Estimated Maximum Gas Retention from Uniformly Dispersed Bubbles in K-Basin Sludge Stored in Large-Diameter Containers. PNNL-13893, Pacific Northwest National Laboratory, Richland, Washington.

Gauglitz PA, SD Rassat, MR Powell, RR Shah, and LA Mahoney. 1995. Gas Bubble Retention and its Effect on Waste Properties: Retention Mechanisms, Viscosity, and Tensile and Shear Strength. PNL10740, Pacific Northwest Laboratory, Richland, Washington.

Gauglitz PA, SD Rassat, PR Bredt, JH Konynenbelt, SM Tingey, and DP Mendoza. 1996. Mechanisms of Gas Bubble Retention and Release: Results for Hanford Waste Tanks 241-S-102 and 241-SY-103 and Single-Shell Tank Simulants. PNNL-11298, Pacific Northwest National Laboratory, Richland, Washington.

Giddings JC. 1991. Unified Separation Science. Wiley-Interscience, New York.

Grambow B, and R Muller. 2001. "First-Order Dissolution Rate Law and the Role of Surface Layers in Glass Performance Assessment." Journal of Nuclear Materials 298:112-24.

Grenthe I, J Fuger, RJM Konings, RJ Lemire, AB Muller, C Nguyen-Trung Cregu, and H Wanner. 1992. "Chemical Thermodynamics of Uranium." In: Chemical Thermodynamics, Volume 1. H Wanner and I Forest, Eds. Elsevier, Amsterdam.

Guo J, C Tiu, PHE Uhlher, and TN Fang. 2003. "Yielding Behaviour of Organically Treated Anatase $\mathrm{TiO}_{2}$ Suspension. Korea-Australia Rheology Journal 15(1):9-17.

Gutsche CD. 1998. Calixarenes Revisited. Royal Society of Chemistry, Cambridge. 
Hay BP, and RD Hancock. 2001. "The Role of Donor Group Orientation as a Factor in Metal Ion Recognition by Ligands.” Coordination Chemistry Reviews 212:61-78.

Hay BP, and TK Firman. 2002. "HostDesigner: A Program for the de Novo Structure-Based Design of Molecular Receptors with Binding Sites that Complement Metal Ion Guests." Inorganic Chemistry 41(21):5502-5512.

Irving H, and RJP Williams. 1948. "Order of Stability of Metal Complexes.” Nature 162(4123):746747.

Jansen M, and JC Schön. 2006. "Design" in Chemical Synthesis-An Illusion?" Angewandte ChemieInternational Edition 45(21):3406-3412.

Johnson RD, and LG Bachas. 2003. "Ionophore-Based Ion-Selective Potentiometric and Optical Sensors." Analytical and Bioanalytical Chemistry 376(3):328-341.

Krupka KM, HT Schaef, BW Arey, SM Heald, WJ Deutsch, MJ Lindberg, and KJ Cantrell. 2006. "Residual Waste from Hanford Tanks 241-C-203 and 241-C-204. Part I. Solids Characterization." Environmental Science \& Technology 40(12):3749-3754.

Larson RG. 1999. The Structure and Rheology of Complex Fluids. Oxford University Press, New York. Laxton PB and JC Berg. 2005. "Gel Trapping of Dense Colloids." Journal Colloid and Interface Science 285(1):152-157.

Lehn J-M. 1973. "Design of Organic Complexing Agents. Strategies Towards Properties.” In: Alkali Metal Complexes with Organic Ligands. JD Dunitz, Ed. Springer, Berlin, Volume 16 of the series Structure \& Bonding 16:1-69.

Lehn J-M, JL Atwood, JED Davies, DD MacNicol, and F Vögtle. 1996. Molecular Recognition: Receptors for Cationic Guests, Pergamon Press, New York, Volumes 1-10, Comprehensive Supramolecular Chemistry. Volume 1, Molecular Recognition: Receptors for Cationic Guests. JL Atwood, JED Davies, DD MacNicol, and F Vogtle, Executive Editors; J-M Lehn, Chairman, Editorial Board; GW Gokel, Volume Editor.

Lemire R, J Fuger, H Nitsche, P Potter, MH Rand, J Rydberg, K Spahiu, JC Sullivan, WJ Ullman, P Vitorge, and H Wanner. 2001. "Chemical Thermodynamics of Neptunium and Plutonium." In: Chemical Thermodynamics, Volume 2. Elsevier, Amsterdam.

Li H, L Li, DM Strachan, and M Qian. 2004. "Optical Spectroscopy Study of Neodymium in Sodium Alumino-Borosilicate Glasses.” Journal of Non-Crystalline Solids 349:127-32.

Li H, L Li, M Qian, DM Strachan, and Z Wang. 2005. "Structure of Glass-Forming Melts - Lanthanide in Borosilicates." In: Melt Chemistry, Relaxation, and Solidification Kinetics of Glasses. Eds. H Li, et al., Vol 170, pp. 69-80. American Ceramic Society, Westerville, Ohio.

Llorens J, E Rudé, and C Mans. 2007. "Structural Models to Describe Thixotropic Behavior." In: Trends in Colloid and Interface Science X. In: Progress in Colloid and Polymer Science, Volume 100, pp. 252-258. C Solans, MR Infante, and MJ Garcia-Celma, Eds. Springer, New York. 
Lumetta GJ. 2004. "The Problem with Anions in the DOE Complex." In: Fundamentals and Applications of Anion Separations. BA Moyer and RP Singh, Eds. Kluwer Academic/Plenum, New York, pp 107-114.

McGrail BP, DH Bacon, JP Icenhower, FM Mann, RJ Puigh, HT Schaef, and SV Mattigod. 2001. "Near-Field Performance Assessment for a Low-Activity Waste Glass Disposal System: Laboratory Testing to Modeling Results." Journal of Nuclear Materials 298:95-111.

Marchisio DL and RO Fox. 2005. "Solution of Population Balance Equations Using the Direct Quadrature Method of Moments." Journal of Aerosol Science 36(1):43-73.

Meacham JE, AB Webb, MG Plys, SJ Lee, JM Grigsby, PG Heasler, JL Bryant, JJ Toth, and PM Daling. 1996. Safety Criteria for the Organic Watch List Ranks at the Hanford Site. WHC-SD-WM-SARR-033, Rev. 1, Westinghouse Hanford Company, Richland, Washington.

Meyer PA, and AW Etchells. 2007. "Mixing with Intermittent Jets with Application in Handling Radioactive Waste Sludges.” Chemical Engineering Research \& Design 85(A5):691-696, doi:10.1205/cherd06182

Miller JE, NE Brown, JL Krumhans1, DE Trudell, RG Anthony, and CV Philip. 1998. "Development and Properties of Cesium Selective Crystalline Silicotitanate (CST) Ion Exchangers for Radioactive Waste Applications.” In: Science and Technology for Disposal of Radioactive Tank Wastes. WW Schultz, NJ Lombardo, Eds. Plenum Press, New York, pp 269-286.

Moyer BA. 1996. “Complexation and Transport.” In Volume 1, Molecular Recognition: Receptors for Cationic Guests. Pergamon, New York, Volumes 1-10, Comprehensive Supramolecular Chemistry. JL Atwood, JED Davies, DD MacNicol, and F Vogtle, Executive Editors; J-M Lehn, Chairman, Editorial Board; GW Gokel, Volume Editor.

Moyer BA, JF Birdwell, Jr., PV Bonnesen, and LH Delmau. 2005. "Use of Macrocycles in NuclearWaste Cleanup: A Realworld Application of a Calixcrown in Cesium Separation Technology." In: Macrocyclic Chemistry_Current Trends and Future Perspectives. K Gloe, Ed., Springer, Dordrecht, pp 383-405.

Moyer BA, LH Delmau, CJ Fowler, A Ruas, DA Bostick, JL Sessler, E Katayev, GD Pantos, JM Llinares, MA Hossain, SO Kang, and K Bowman-James. 2006. "Supramolecular Chemistry of Environmentally Relevant Anions." In: Advances in Inorganic Chemistry (series), Template Effects and Molecular Organization. R van Eldik and K Bowman-James, Eds. Elsevier, Amsterdam, Volume 59, Chapter 5, pp 175-204.

National Research Council (NRC). 1997. Building an Effective Environmental Management Science Program: Final Assessment. Washington, D.C., National Academies Press. http://books.nap.edu/catalog.php?record_id=5557. Accessed April 23, 2008.

National Research Council (NRC). 2000. Alternatives for High-Level Waste Salt-Processing at the Savannah River Site. Washington, D.C., National Academies Press. http://books.nap.edu/catalog.php?record_id=9959. Accessed April 23, 2008. 
National Research Council (NRC). 2001. A Strategic Vision for Department of Energy Environmental Quality Research and Development. Washington, D.C., National Academies Press. http://books.nap.edu/catalog.php?record_id=10207. Accessed April 23, 2008.

National Research Council (NRC). 2003. Improving the Scientific Basis for Managing DOE's Excess Nuclear Materials and Spent Nuclear Fuel. Washington, D.C., National Academies Press. http://www.nap.edu/catalog.php?record_id=10684. Accessed April 23, 2008.

National Research Council (NRC). 2005. Improving the Characterization and Treatment of Radioactive Wastes for the Department of Energy's Accelerated Site Cleanup Program. Washington, D.C., National Academies Press. http://books.nap.edu/catalog.php?record_id=11200. Accessed April 23, 2008.

National Research Council (NRC). 2006. Tank Waste Retrieval, Processing, and On-Site Disposal at Three Department of Energy Sites. Washington, D.C., National Academies Press. http://www.nap.edu/catalog.php?record_id=11618. Accessed April 23, 2008.

National Research Council (NRC). 2007. Science and Technology Needs for DOE Site Cleanup: Workshop Summary. Washington, D.C., National Academies Press. http://www.nap.edu/catalog.php?record_id=11932. Accessed April 23, 2008.

Peters MT, RC Ewing, and CI Steefel. 2008. GNEP Waste Form Campaign Science \& Technology and Modeling \& Simulation Program: Roadmap with Rationale \& Recommendations. GNEP-M50-3040-303, U.S. Department of Energy, Office of Nuclear Energy, Washington, D.C.

Pierce EM, BP McGrail, PF Martin, J Marra, BW Arey, and KN Geiszler. 2007. “Accelerated Weathering of High-Level and Plutonium-Bearing Lanthanide Borosilicate Waste Glasses under Hydraulically Unsaturated Conditions." Applied to Geochemistry-Accepted for publication.

Poloski AP, RC Daniel, DR Rector, PR Bredt, EC Buck, JC Berg, and AE Saez. 2006. Characterization and Correlation of Particle-Level Interactions to the Macroscopic Rheology of Powders, Granular Slurries, and Colloidal Suspensions. PNNL-16133, Pacific Northwest National Laboratory, Richland, Washington.

Poloski AP, BE Wells, JM Tingey, LA Mahoney, MN Hall, SL Thomson, GL Smith, ME Johnson, JE Meacham, MA Knight, MG Thien, JJ Davis, and Y Onishi. 2007. Estimate of Hanford Waste Rheology and Settling Behavior. PNNL-16857, Pacific Northwest National Laboratory, Richland, Washington.

Rana MA, and RW Douglas. 1961. "The Reaction between Glass and Water. Part I. Experimental Methods and Observations." Physics and Chemistry of Glasses 2:179-95.

Rassat SD, PA Gauglitz, PR Bredt, LA Mahoney, SV Forbes, and SM Tingey. 1997. Mechanisms of Gas Bubble Retention and Release: Experimental Results for Hanford Waste Tanks 241-AW-101 and 241-AN103. PNNL-11642, Pacific Northwest National Laboratory, Richland, Washington.

Rassat SD, SM Caley, PR Bredt, PA Gauglitz, DE Rinehart, and SV Forbes. 1998. Mechanisms of Gas Bubble Retention and Release: Experimental Results for Hanford Single Shell Waste Tanks 241-A-101, 241-S-106, and 241-U-103. PNNL-11981, Pacific Northwest National Laboratory, Richland, Washington. 
Rossen WR, and SI Kam. 1996. Mechanisms of Stability of Armored Bubbles: FY 1996 Final Report. PNNL-11416, Richland, Washington.

Ruthven DM. 1997. Encyclopedia of Separation Technology. John Wiley \& Sons, New York.

Schmidtchen FP. 2006. "Reflections on the Construction of Anion Receptors-Is There a Sign to Resign from Design?” Coordination Chemistry Reviews 250(23-24):2918-2928.

Shaw DJ. 1980. Introduction to Colloid Chemistry. Butterworths, Boston, Massachusetts.

Kennedy D, C Norman, T Siegfried, C Seife, G Miller, E Pennisi, J Couzin, RJ Davenport, G Vogel, RA Kerr, C Zimmer, C Culotta, RF Service, J Cohen, and E Stokstad.. 2005. "What Don't We Know." Science 309(5731):78-102.

Silva R, G Bidoglio, MH Rand, PB Robouch, H Wanner, and I Puigdomenech. 1995. "Chemical Thermodynamics of Americium." In Chemical Thermodynamics, Volume 2. Elsevier, Amsterdam.

Stewart CW, ME Brewster, PA Gauglitz, LA Mahoney, PA Meyer, KP Recknagle, and HC Reed. 1996. Gas Retention and Release Behavior in Hanford Single-Shell Tanks. PNNL-11391, Pacific Northwest National Laboratory, Richland, Washington.

Sundaram SK, PP Woskov, JS Machuzak, and WE Daniel, Jr. 2002. “Cold Cap Monitoring Using Millimeter Wave Technology.” In: Environmental Issues and Waste Management Technologies in the Ceramic and Nuclear Industries VII, Ceramic Transactions, Volume 132, Editors: SK Sundaram, G Smith, and DR Spearing, The American Ceramic Society, ISBN 1-57498-146-3, pp. 203-213, April 2002.

Terrones G, and PA Gauglitz. 2003. "Deformation of a Spherical Bubble in Soft Solid Media Under External Pressure." Quarterly Journal of Mechanics and Applied Mathematics 56(4):513-525.

U.S. Department of Energy (DOE). 1998a. Environmental Management Strategic Plan for Science \& Technology. DOE, Washington, D.C. http://www.p2pays.org/ref/14/13636.pdf. Accessed April 23, 2008.

U.S. Department of Energy (DOE). 1998b. Environmental Management Research and Development Plan: Solution-Based Investments in Science and Technology. DOE, Washington, D.C.

U.S. Department of Energy (DOE). 2006. U.S. Department of Energy Strategic Plan. DOE, Washington, D.C. http://www.energy.gov/media/2006_DOE_Strategic_Plan.pdf. Accessed April 23, 2008.

U.S. Department of Energy (DOE). 2008a. Engineering and Technology Program Management Plan. DOE, Washington, D.C. http://www.em.doe.gov/pdfs/08N00100_72dpi.pdf. Accessed April 23, 2008.

U.S. Department of Energy (DOE). 2008b. Engineering \& Technology Roadmap: Reducing Technical Risk and Uncertainty in the EM Program. Washington, D.C.

http://www.em.doe.gov/pdfs/FINAL\%20ET\%20Roadmap\%20_3-5-08_.pdf. Accessed April 23, 2008. 
U.S. Department of Energy (DOE). 2008c. Waste Processing Multi-Year Program Plan Fiscal Year 2008-2012. Washington, D.C. http://www.em.doe.gov/pdfs/MYPP\%205.23.pdf. Accessed June 21, 2008.

Van Iseghem P, S Gin, B Grambow, BP McGrail, D Strachan, and GG Wicks. 2003. Glamour. A Critical Evaluation of the Dissolution Mechanisms of High Level Waste Glasses in Conditions of Relevance for Geological Disposal. Progress Report 2001-11-01 to 2003-01-31. Technical Rpt. R-3702, SCK CEN, Mol, Belgium.

Wang P, A Anderko, and RD Young. 2002. "A Speciation-Based Model for Mixed-Solvent Electrolyte Systems.” Fluid Phase Equilibria 203(1-2):141-176.

Wang P, RD Springer, A Anderko, and RD Young. 2004a. "Modeling Phase Equilibria and Speciation in Mixed-Solvent Electrolyte Systems.” Fluid Phase Equilibria 222-223:11-17.

Wang P, A Anderko, and RD Young. 2004b. "Modeling Electrical Conductivity in Concentrated and Mixed-Solvent Electrolyte Solutions." Industrial and Engineering Chemistry Research 43(25):80838092.

Wang P, A Anderko, RD Springer, and RD Young. 2006. "Modeling Phase Equilibria and Speciation in Mixed-Solvent Electrolyte Systems: II. Liquid-Liquid Equilibria and Properties of Associating Electrolyte Solutions." Journal of Molecular Liquids 125(1):37-44.

Wasan D, A Nikolov, and A Shah. 2004. "Foaming-Antifoaming in Boiling Suspensions." Industrial \& Engineering Chemistry Research 43(14):3812-3816.

Wells BE, MA Knight, EC Buck, RC Daniel, SK Cooley, LA Mahoney, PA Meyer, AP Poloski, JM Tingey, WS Callaway, III, GA Cooke, ME Johnson, MG Thien, DJ Washenfelder, JJ Davis, MN Hall, G Smith, SL Thomson, and Y Onishi. 2007. Estimate of Hanford Waste Insoluble Solid Particle Size and Density Distribution. WTP-RPT-153, Rev. 0, Battelle-Pacific Northwest Division, Richland, Washington.

Wilkenson G, RD Gillard, and JA McCleverty, Eds. 1987. Comprehensive Coordination Chemistry. Pergamon Press, Oxford, Vols. 1-7.

Yokoyama T, S Okumura, and S Nakashima. 2008. "Hydration of Rhyolitic Glass During Weathering as Characterized by IR Microspectroscopy.” Geochimica et Cosmochimica Acta 72:117-25.

Zhang YH, A Navrotsky, H Li, LY Li, LL Davis, and DM Strachan. 2001. "Energetics of Dissolution of $\mathrm{Gd}_{2} \mathrm{O}_{3}$ and $\mathrm{HfO}_{2}$ in Sodium Alumino-Borosilicate Glasses." Journal of Non-Crystalline Solids 296:93-101.

Zhou Z, PJ Scales, and DV Boger. 2001. "Chemical and Physical Control of the Rheology of Concentrated Metal Oxide Suspensions.” Chemical Engineering Science 56(9):2901-2920.

Zwietering TN. 1958. "Suspending of Solid Particles in Liquid by Agitators." Chemical Engineering Science 8(3-4):244-253. 